\title{
Early medieval shellfish gathering at the Sands of Forvie, Aberdeenshire: feast or famine?
}

\author{
Gordon Noble ${ }^{1}$, Joe Turner ${ }^{2}$, Derek Hamilton ${ }^{3}$, Lee Hastie ${ }^{4}$, \\ Rick Knecht ${ }^{1}$, Lindsey Stirling 5 , Oskar Sveinbjarnarson ${ }^{1}$, \\ Beth Upex ${ }^{6}$ and Karen Milek ${ }^{1}$
}

\begin{abstract}
From 2010 to 2014, extensive shell middens were excavated at the Sands of Forvie, Aberdeenshire, and the wider landscape explored through a programme of soil and geophysical survey. The middens were dated to the 1st millennium $A D$ and appear to represent intensive gathering and cooking of shellfish, particularly mussels. To date, few middens of the scale of the Forvie examples have been identified in Scotland, but the middens share some parallels with similar examples found in a broader North Sea context. This article reports on the findings of the excavations, provides an outline of the chronology of the middens, including Bayesian modelling of dates, and a brief review of the growing evidence for shellfish gathering in 1st-millennium AD Scotland and the wider north-west European context.
\end{abstract}

\section{INTRODUCTION}

The Sands of Forvie is an extensive area of shifting sand dunes in north-east Scotland, the fifth largest in Britain, and is a designated National Nature Reserve (Ritchie 1983; Scottish Natural Heritage 2009). The movement of windblown sand along this coast, just north of the modern city of Aberdeen, has had a significant impact on human activity in the area, with early dunes established in the south part of the sands from around 2000 cal BC (North 1981; Ritchie 1983; Ritchie 1997; Hansom 2003). The medieval church and settlement at Forvie (Illus 1), now at the centre of the dune system, was overwhelmed by sand in 1413 and by 1680 the whole Parish of Forvie had been abandoned due to sand encroachment (North 1981: 9). It is likely that inundations of sand have also affected human settlement in this area throughout prehistory (see below).

Dynamic aeolian landscapes like the Sands of Forvie can help preserve archaeological sites in a way not often encountered in lowland contexts (Cowie 1996; Ralston 1997: 30; Griffiths \& Ashmore 2011). Indeed, the Sands of Forvie has long been recognised for its archaeological remains (Illus 1). Extensive assemblages of prehistoric lithics have been collected and recorded since the 20th century, including surface collections totalling thousands of pieces (HawkeSmith 1980; see also Warren 2005: 173, table 1). More recent excavations by Graeme Warren (2005) identified small numbers of features - such as hearths - surviving in association with some of the larger lithic scatters. The lithics appear to date mainly to the Mesolithic Period, but later prehistoric material has also been identified and

\footnotetext{
${ }^{1}$ Department of Archaeology, School of Geosciences, University of Aberdeen

${ }^{2}$ Headland Archaeology, Leeds

${ }^{3}$ SUERC Radiocarbon Laboratory

${ }^{4}$ School of Biological Sciences, University of Aberdeen

5 AOC Archaeology, Inverness

${ }^{6}$ Department of Archaeology, University of Durham
} 


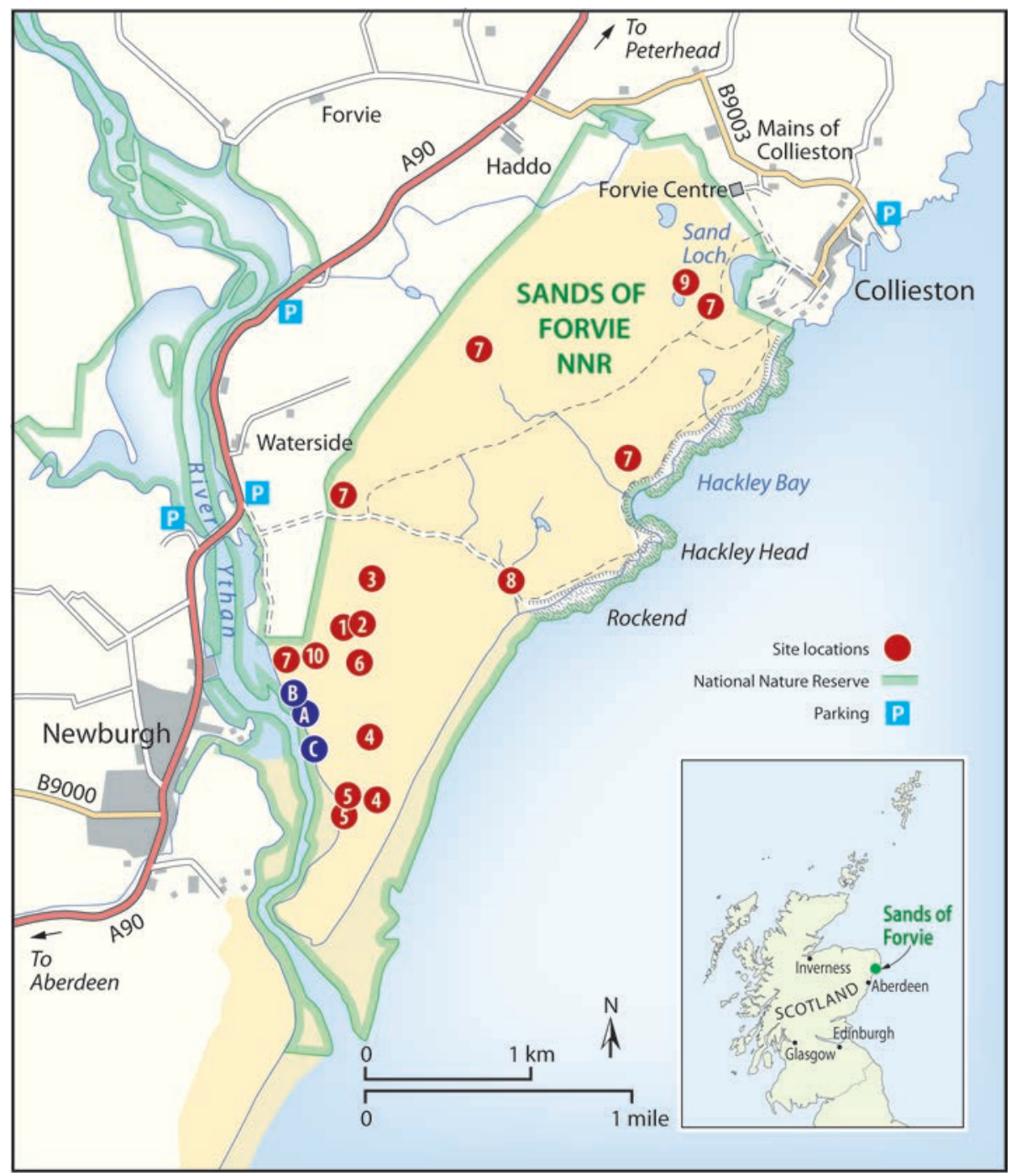

ILlus 1 Map of the Sands of Forvie showing the locations of Middens A, B and C and other sites mentioned in the text: (1) Bronze Age/Iron Age settlement remains; (2) Bronze Age ring and kerb cairns; (3) Bronze Age kerb cairns; (4) Mesolithic flint scatters; (5) Mesolithic flint working areas recorded by Warren; (6) findspot of the Romano-British penannular brooch; (7) areas of medieval rig and furrow seen on aerial photographs; (8) Forvie Kirk and medieval village; (9) turf buildings and enclosure at Cluny Cottages; (10) Iron Age buried soils. Base map (C) Crown Copyright/database right 2016. An Ordnance Survey/EDINA supplied service 
Warren obtained 4th-millennium cal BC dates for some of the features excavated in association with lithic scatters within the dune system near the mouth of the Ythan River (Warren 2005: 2-11). Upriver to the north, lithic scatters (including Mesolithic and Neolithic material) are recorded at a number of sites, suggesting extensive prehistoric use of the lower stretches of the Ythan (eg O'Dell 1960; Sneddon \& Ralston 1984; Sneddon \& Shepherd 1985; Saville 2004).

Later prehistoric-medieval activity is also well attested in the dune systems at the Sands of Forvie. In the 1950s, Kirk identified an extensive Late Bronze Age/Early Iron Age settlement including hut circles, working areas and cairns (Kirk 1954), and excavations in the 1970s revealed a further series of kerb cairns (Ralston 1997: 31-2; Ralston \& Sabine 2001: 147). In 1955, Kirk began work on the church that had been inundated by sands in the medieval period and his excavations soon shifted focus to the medieval village itself (Illus 1) (Kirk 1955; 1957). The area has extensive traces of later medieval rig and furrow farming and the area is also known to have been used extensively for the procurement of mussels for fishing bait from the late medieval and post-medieval periods; the estuary supplied bait for many of the villages along this stretch of the coastline into the 20th century (Farquhar 1799; Rust 1845; Warren 2005: 65).

The existence of a range of shell middens (centred NK 007 258) and associated occupation material at the Sands of Forvie, along both shores of the Ythan estuary, where extensive mussel beds still exist today, has been recognised for over a century (Jamieson 1865; Dalrymple 1868). Jamieson, for example, observed 'flint flakes and chippings' in association with middens located on both sides of the estuary in the $1860 \mathrm{~s}$ (1865: 241), and Dalrymple (1868) recorded the excavation of two middens on the north side of the estuary. Survey work by Warren in the late 1990s identified three substantial surviving middens, but more have been identified in the past (eg Hawkes-Smith 1980: 497, fig 1). Warren conducted a topographic survey at two middens resting on the main post-glacial raised beach (Warren 2005: 65-6). Midden A survives as a low dome-shaped feature, measuring $c 20 \mathrm{~m}$ across, while Midden B is more irregular in shape, measuring $c 35 \mathrm{~m}$ in length (Illus 2). The location of these middens on top of and slumping down the raised shoreline associated with the Main Post-Glacial Transgression (MPGT, occurring between 6000-4870 cal BC) (Ballantyne \& Dawson 2003: 38), suggested to Warren that these two middens were possibly of an early date. The middens were identified as consisting primarily of mussels, with some cockle and winkle shells, and burnt stones. Warren (2005: 66) also described a third midden, Midden $\mathrm{C}$, which is located at a lower elevation than the other two middens and slumps down onto the present shoreline (Illus 2). The fieldwork described here targeted these three middens previously surveyed by Warren and their landscape context. At the time of excavation, all three middens had been damaged by a range of anthropogenic and natural processes. Midden C, in particular, was extensively eroded.

\section{RESULTS}

The fieldwork reported here was designed to evaluate the character and date of the most threatened midden, Midden $\mathrm{C}$, and involved small-scale excavation, geophysical survey, soil survey and post-excavation work. At the time of the work, it was presumed that the middens were prehistoric in date and the project was initially focused on establishing the chronology of the middens; exploring the relationship of the middens to the extensive Mesolithic lithic assemblages and later prehistoric settlement remains known from Forvie. The project also focused on obtaining information from the middens to mitigate the effects of erosion. The results of the excavations of Midden $\mathrm{C}$ and follow-up work at Middens A and B along with the results of work to characterise the wider landscape are outlined below. Post-excavation work focused on assessing the composition of the shell midden layers from Midden C, an assessment of faunal remains, along with radiocarbon dating and Bayesian modelling, the results of which are also reported on here. 


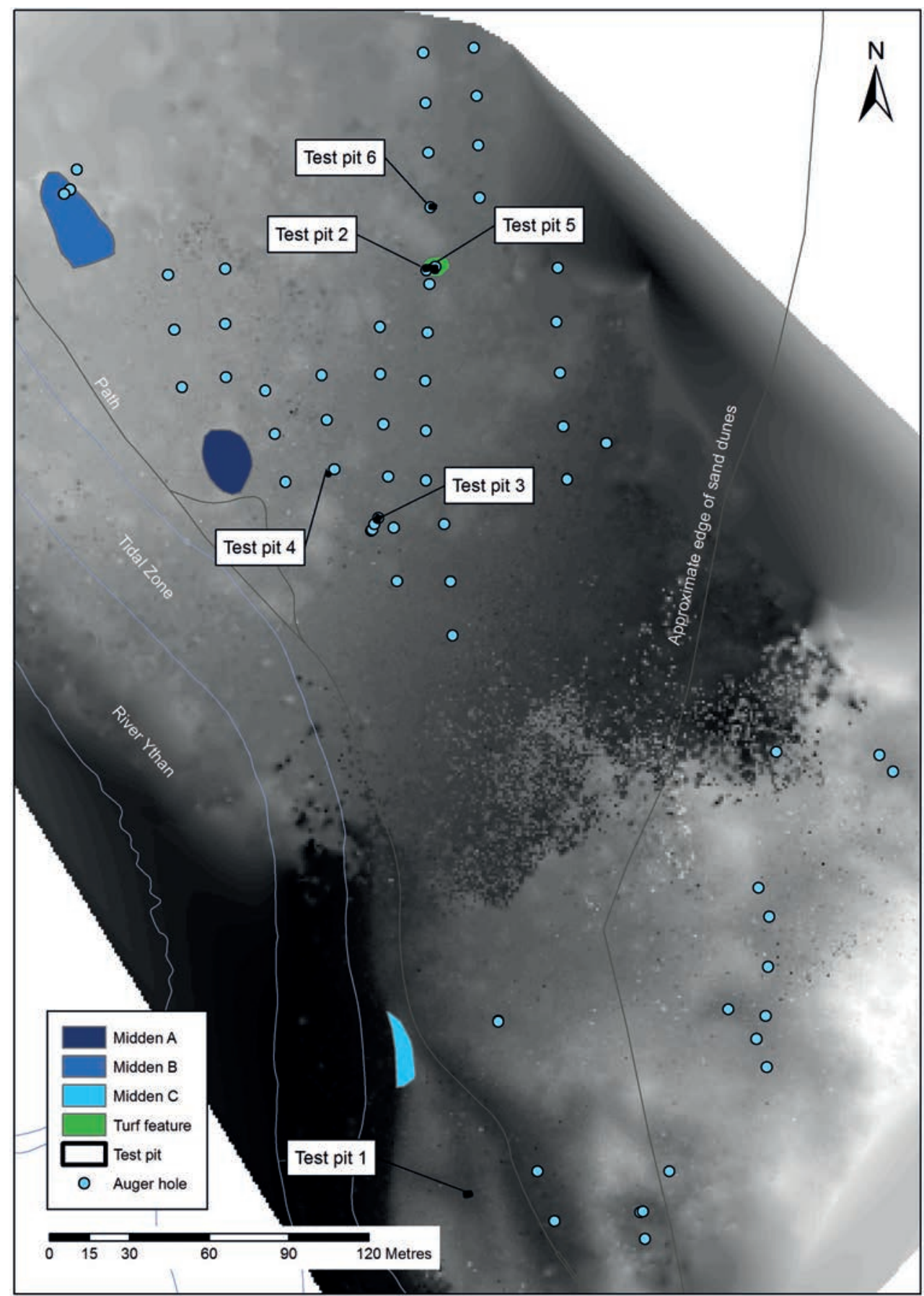

ILLUs 2 Topographical model showing the position of the three middens discussed in the text at Sands of Forvie. Auger survey points from a geoarchaeological analysis are also mapped and the position of a turf structure found near Midden B. Soil pits excavated for geoarchaeological purposes are also labelled. Base map (C) Crown Copyright/database right 2016. An Ordnance Survey/EDINA supplied service 
The fieldwork was conducted in 2010, with the work at Midden $\mathrm{C}$ occurring over a six-day period in April 2010, when the most exposed parts of the eroding section of the midden were cleaned, recorded and sampled. The midden and surrounding area were also augered to establish the extent of the midden deposits through examining the presence/absence of shell layers. In October 2010, a further five-day period of fieldwork was conducted to assess the character and date of Middens A and B. Some soil test pitting to begin the work of characterising the environment around the middens was conducted in October 2010, and the programme of landscape research was intensified in April and July 2014, when magnetometer and soil auger surveys, followed by the digging of additional soil test pits and the partial excavation of a newly discovered turf building, were conducted in low-lying areas between the highest sand dunes as part of an MSc dissertation project. A topographical survey of the area around the middens was also conducted at this time, and a digital terrain model for the area was generated using a combination of dGPS, walkover survey and photogrammetry based on aerial photographs obtained from a kite (Illus 2).

\section{MIDDEN C EXCAVATION RESULTS}

Midden C, located closest to the present high tide line, was in the poorest state at the time of the excavation, with a $c 35 \mathrm{~m}$ long section heavily exposed to erosion, and with many shell and charcoal layers visible for a depth of up to $2 \mathrm{~m}$ (Illus 3). In April 2010, the exposed face of the midden was cleaned using spades and trowels and recorded with scaled section drawings and photography. Particular areas of the exposed section were targeted for more intensive analysis (Illus 4). Near the southern edge of the cleaned section, a $0.75 \mathrm{~m} \times 0.5 \mathrm{~m}$ column (Column A) was excavated through the upper midden layer, and a stepped section was dug through windblown sand deposits and lower midden layers (Illus 5). 10.5m to the north, a further column (Column B) was excavated through the upper shell midden and a further section (Column C) was dug between them, providing additional detail about the lower part of the midden stratigraphy. An auger survey of the midden established that the upper shell midden deposits extended to around 35m north/ south, but due to erosion had an east/west width of only $2-4 \mathrm{~m}$ surviving.

\section{Column A}

Over $2.9 \mathrm{~m}$ of deposits were identified in Column A, lying on top of compact sands and rounded beach pebbles of a raised beach. The lowest layer of archaeological significance identified was a mottled brown and yellowish sand layer (49), up to $0.46 \mathrm{~m}$ thick. On top of this lay a layer of silty brown sand (47), with a significant shell component $(20 \%)$, and charcoal. The shells found at this level indicate a lower midden layer of mussels and a small proportion of periwinkle (Table 1). This lower midden layer was covered by around $1 \mathrm{~m}$ of windblown sand (Contexts 45 and 41) that had only intermittent evidence of human activity within, including a thin lens of burnt shell, charcoal and soil (37), representing an ephemeral activity event. The two major sand layers (45 and 41) formed a substantial sand dune. On top of the windblown sand, layers of charcoal, shell and silty sand (40, 39 and 38) were identified below another thick sand deposit (10), and it was on this latter deposit of windblown sand that the upper shell midden levels were identified. The upper shell midden deposits were much more shell-rich, suggestive of more rapid deposition of shells than occurred in the lower midden levels.

The upper shell midden deposits in Column A consisted of deposits around $1 \mathrm{~m}$ in depth, with three main shell layers interleaved with thin layers of sand. The primary shell midden layer (8) lay on top of a thin charcoal lens (9), was $0.23 \mathrm{~m}$ at its thickest extent and mainly composed of mussels with small numbers of periwinkle, cockle and clam shells (Table 1). This shell midden layer was separated from a second layer by a further charcoal lens (7), with a high shell component, and a layer of dark grey/brown sand (6), perhaps a developed soil level or upcast from digging elsewhere on the midden. The secondary shell midden layer in the upper midden (5) was around $0.16 \mathrm{~m}$ in maximum thickness and was composed of mussel and periwinkle (Table 1). A further layer of sand (4) lay on top and the final 


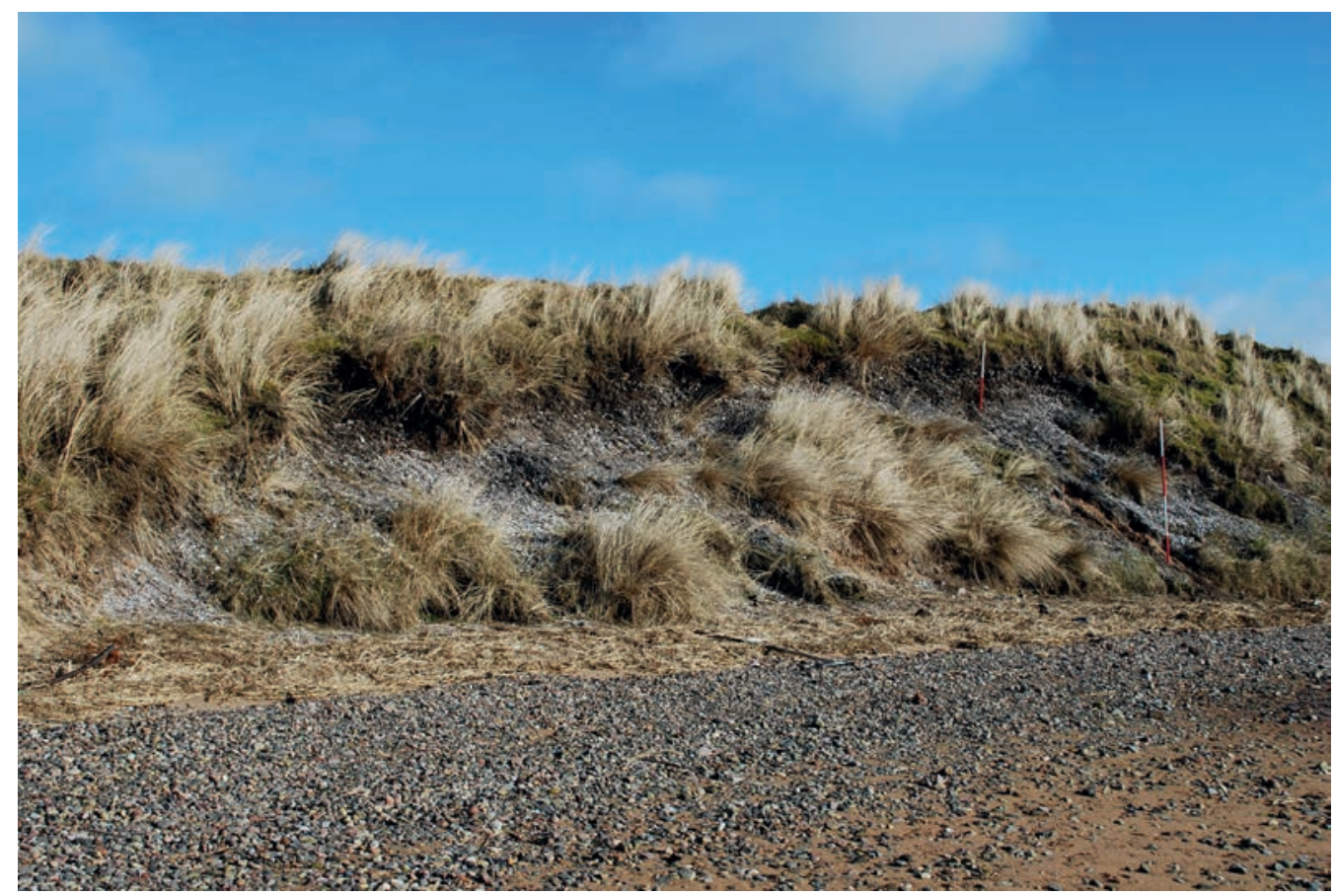

ILlus 3 Midden C prior to excavation. The eroding shell deposits can be seen slumping down onto the present shore and beach level

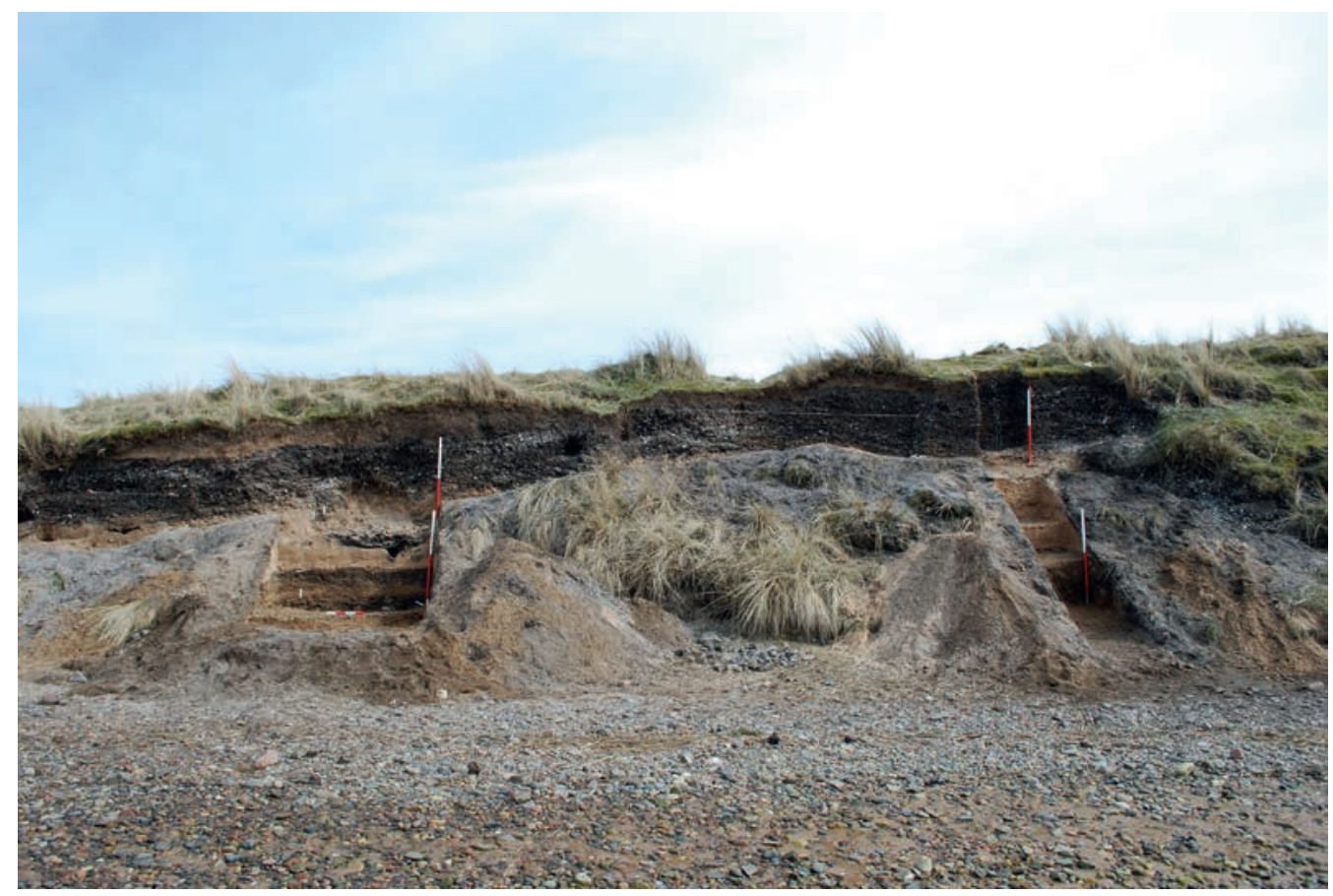

ILlus 4 Midden C post-excavation photograph showing Column A and Column C excavated through the midden 


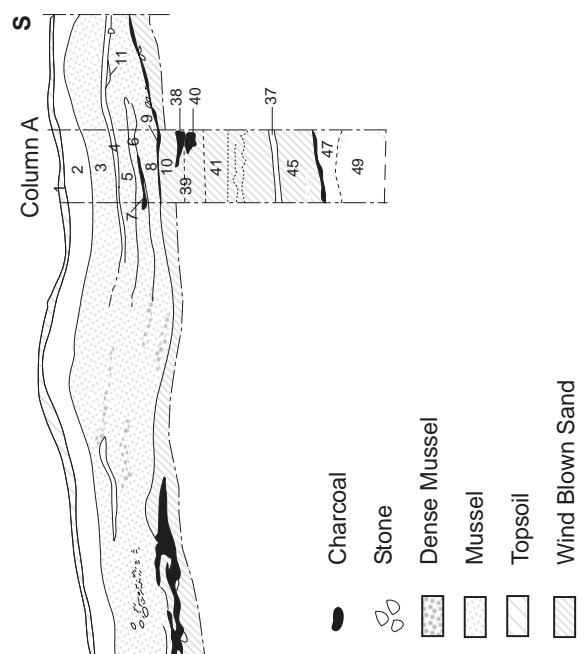

shell midden layer in the upper midden was the thickest of the three, around $0.36 \mathrm{~m}$ at its deepest extent (3), with over 99\% mussel shell and a small proportion of periwinkle (Table 1). In the uppermost part of the Column A section, shells became less frequent and the soil matrix darker in colour and more loamy. On top of the final shell midden layer, top soil and the present turf layer had formed.

\section{Column B}

Column B (Illus 5) was excavated to investigate a series of charcoal lenses identified at the base of the upper shell midden layers. These lenses proved to be situated within pits dug into the sand dune upon which the upper midden had formed. At least two pits were identified. Feature 35 was a small pit cut by a larger pit (26). Pit 35 contained a small proportion of shell $(20 \%)$ and charcoal flecking. Pit 26 , around $0.68 \mathrm{~m}$ in diameter, had a richer charcoal fill, but with less shell and some fire-cracked rock. Above these features in the upper midden layers was a similar series of deposits to that found in Column A. These included at least three distinct shell midden layers (21, 20 and 16), interspersed with intermittent evidence for soil accumulation and discrete sand layers.

\section{Column C}

The most illuminating column dug in the 2010 excavations was Column C (Illus 5), which was excavated to investigate a pit identified in the eroding section and a concentration of firecracked stones found on top of the sand dune deposits that underlie the upper midden. The lowest layers identified in Column C lay on top of raised beach deposits. The uppermost of these was Context 42, a brown silty sand with a high shell component ( $c 50 \%$ ) and occasional charcoal (mussels and periwinkle, Table 1). As in Column A, this lower shell midden layer lay on top of a mottled brown/yellow sand layer, which in turn lay on top of a shallow, but significant layer of charcoal and burnt stone (44).

Above these lower midden layers lay a thick deposit of windblown sand, as identified in 
TABLE 1

Shell proportions as identified at Midden C. Mussel percentages highlighted in red. Data analysed by Lee Hastie

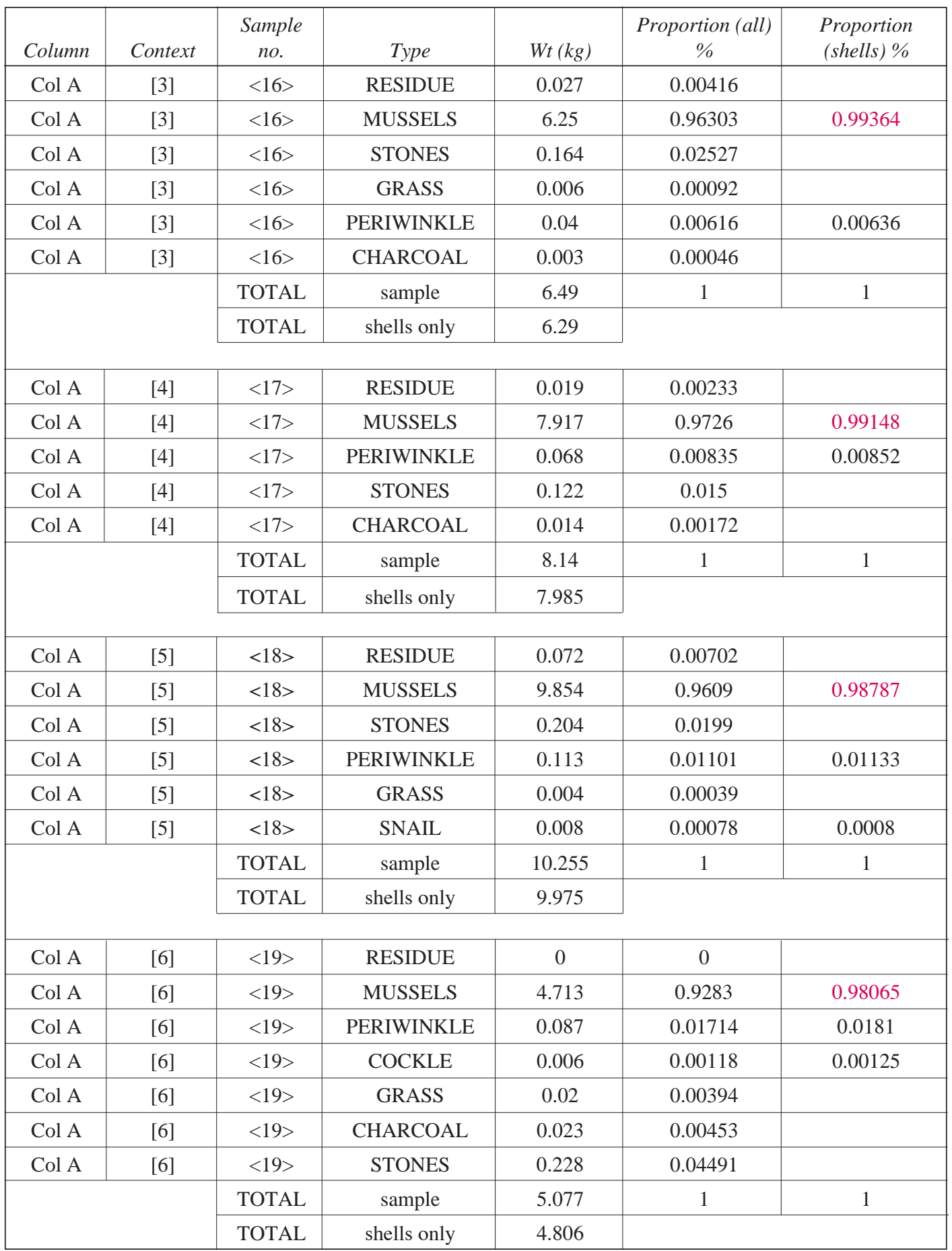




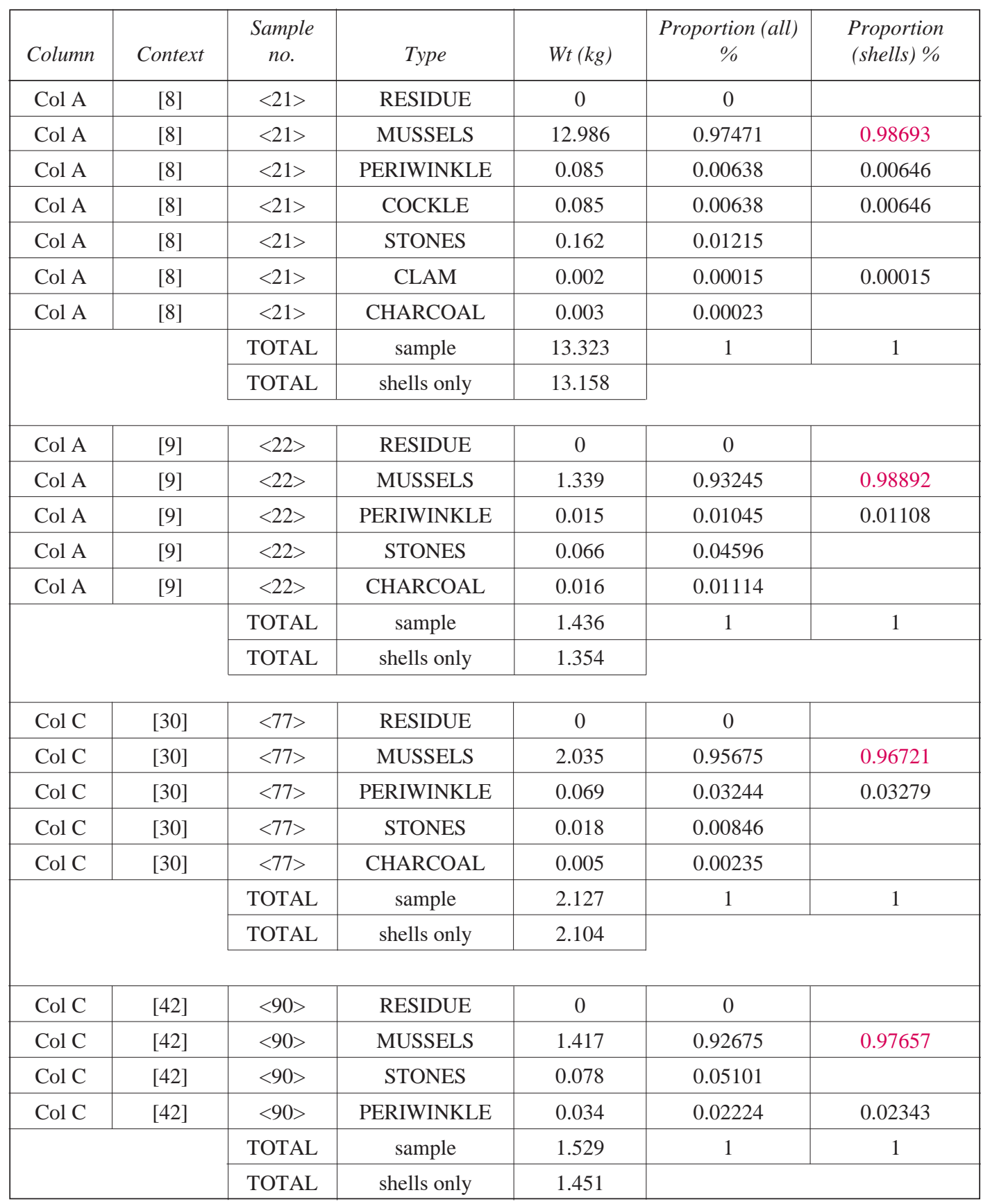




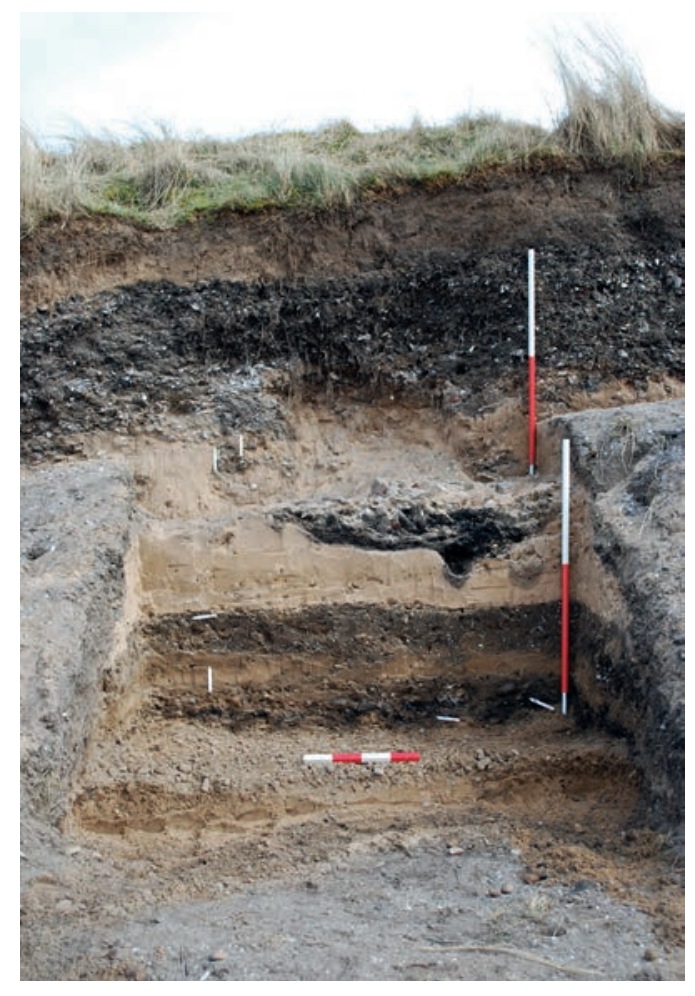

ILLus 6 Fire Pit 031 cut into the major windblown sand layers separating the lower midden and upper shell midden deposits in Column $\mathrm{C}$
Column A. Within the windblown sand deposits a large fire pit (31) was identified (Illus 6). The pit measured around $1.15 \mathrm{~m}$ north/south $\times 0.75 \mathrm{~m}$ east/west. The upper matrix of the pit consisted largely of heat-affected stones (32), including examples of in situ fire-cracked stones. These stones, like the majority of fire-cracked stones found in association with the midden levels, were fist-sized or greater, and of a different character and larger size than those generally found on the present-day estuarine shore. Within and just above the stones, a yellow sand matrix contained numerous shells, including a notable number of whole shells (29). Below the fire-cracked stones was an in situ burnt deposit consisting of a compact, nearly pure charcoal layer, including large charred twigs and small branches (33). The feature showed evidence of sand reddening towards the base of the fill. A brown sandy loam deposit (34) was found to extend below and to the western side of the fire pit. The basal fill consisted of a sandy loam with the character of burnt peat or turf, and pieces of charred peat were recovered from this deposit during flotation of soil samples. A flake of flint was also found in the lower fills of the pit. The pit itself may have been reused, as below the base of Context 34, a thin

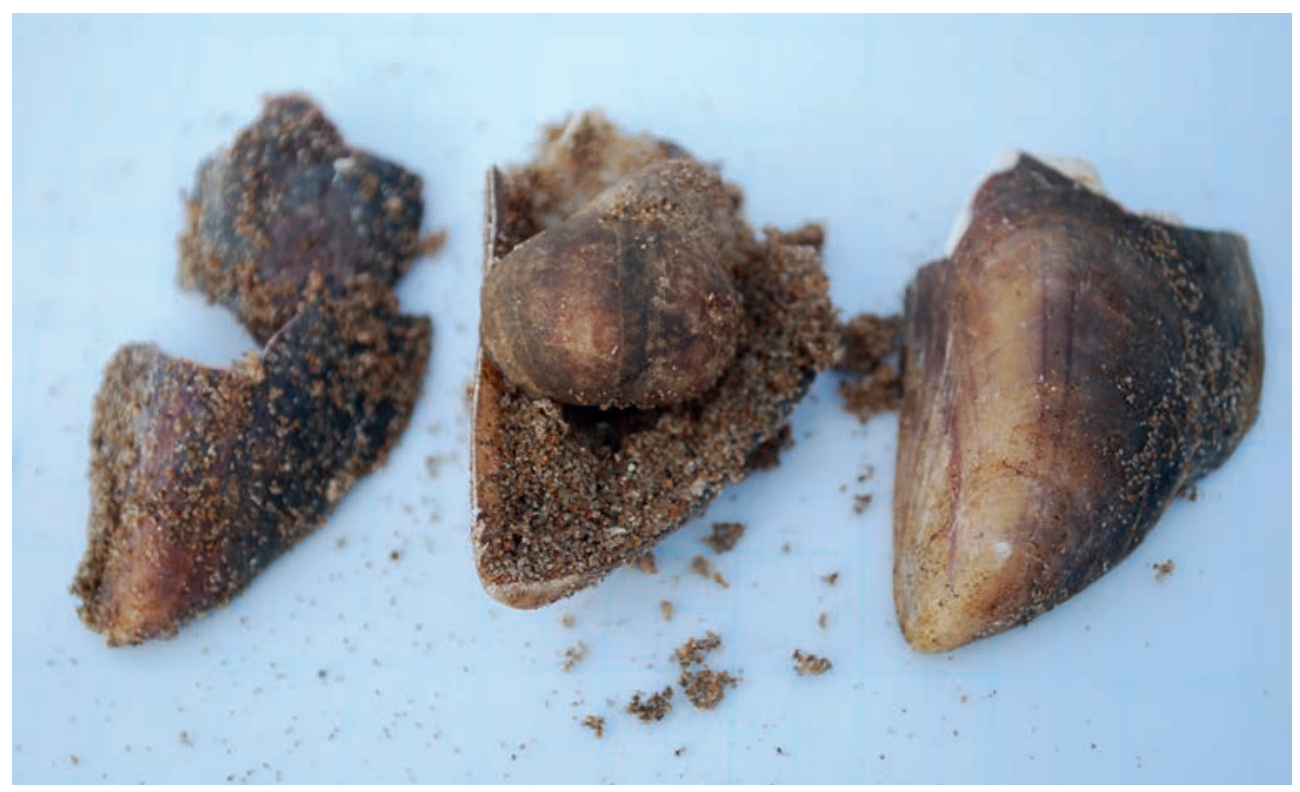

ILlus 7 An example of shell discard at Midden C. Periwinkle found within two nested mussel shells 


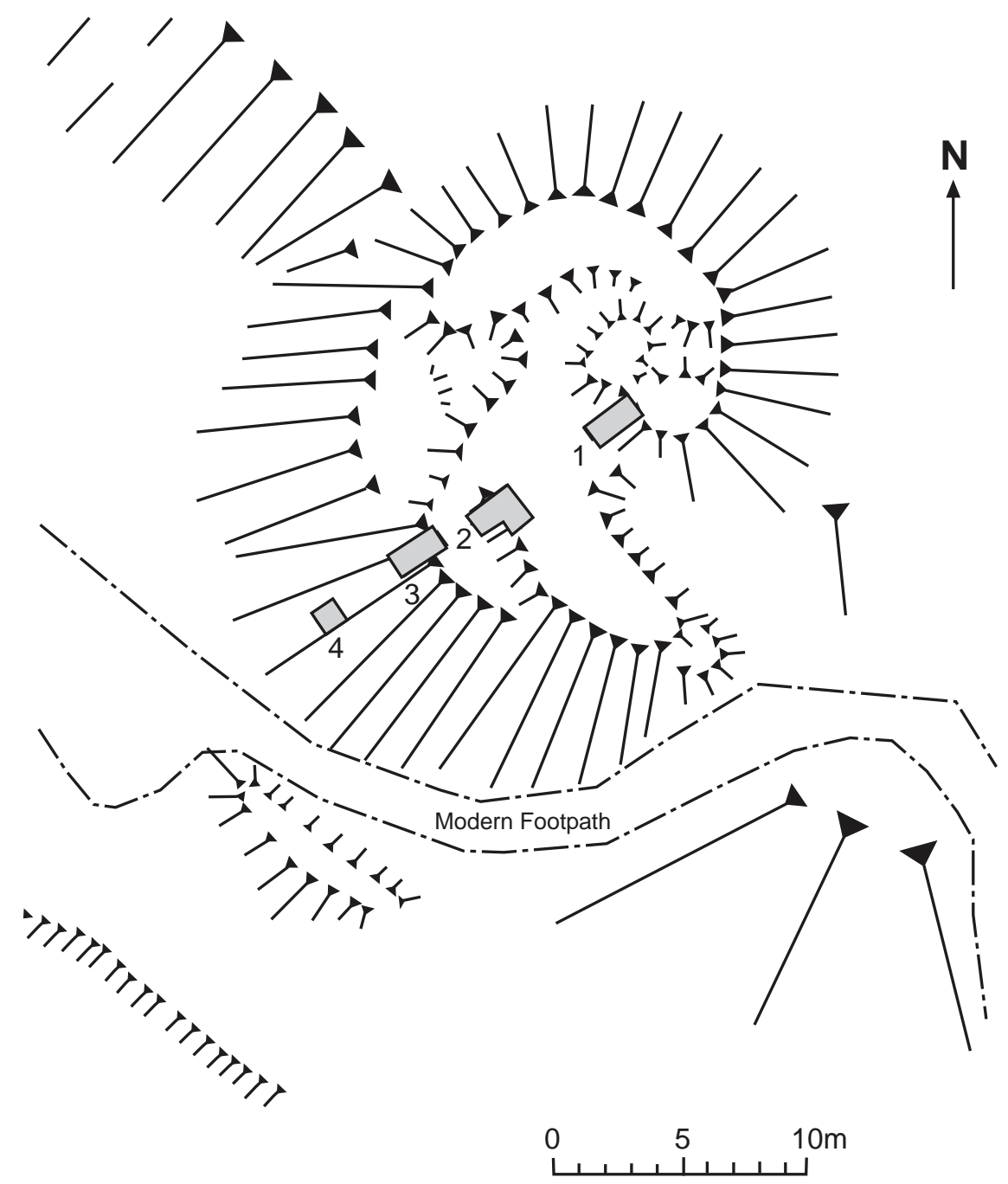

ILLUS 8 Hachure survey of Midden A with trench locations marked. Hachure survey based on data from Warren 2005

lens of charcoal and shell was evident - perhaps the remnants of an earlier fire set within a similar pit feature.

In Column $\mathrm{C}$ the upper midden had the same general character as revealed elsewhere, with around $0.7 \mathrm{~m}$ of shell midden deposit sandwiched between the modern topsoil and lower sand dune deposits (Illus 5). Pit 29 was cut from the upper midden levels, but extended down into the lower sand dune deposits. The fill consisted largely of shells in the upper part of the pit, with lower levels of shell farther down in the fill and increasing levels of charcoal including larger fragments of charred wood. Within the lower fills of the feature, details were revealed about shell discard practices on the midden - within the fill two nested mussel shells were found, with a large periwinkle shell clasped inside (Illus 7). The nested shells indicate that the discard of shells was not always entirely expedient - small-scale 


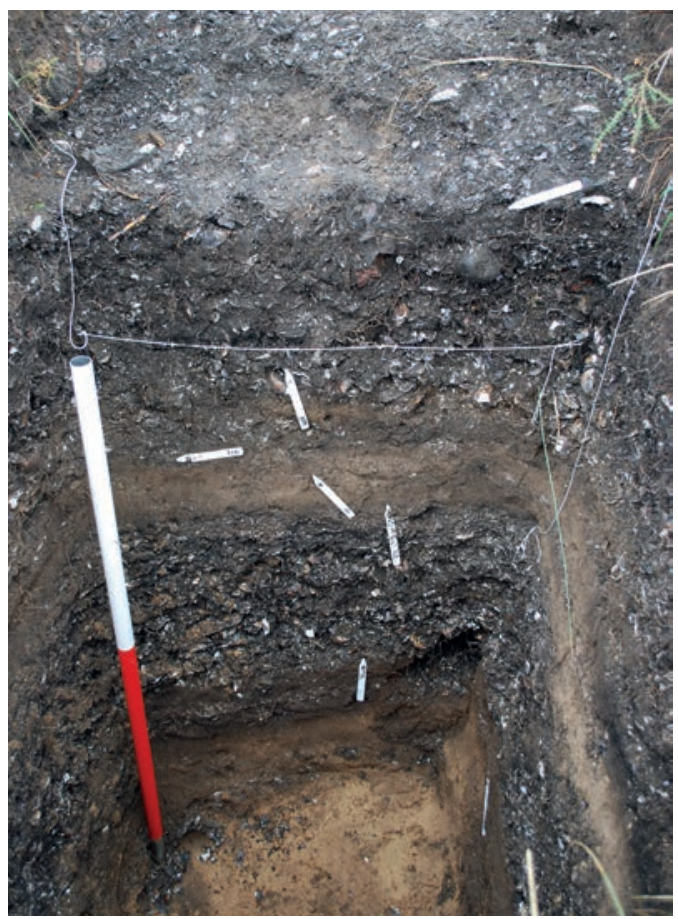

ILLUS 9 South-west facing section of SQ1 showing two major midden layers

acts of creativity or idle play were involved in the creation of the midden piles.

\section{MIDDEN A EXCAVATION RESULTS}

Midden A is located $c 200 \mathrm{~m}$ from Midden C and sits atop the main MPGT raised beach (Illus 1 and 2 ). The densest part of the midden is above the ancient shoreline, but the midden layers slump down over the face of the ancient shoreline for a distance of around $10 \mathrm{~m}$. Four test pits (SQ14) were laid out in a transect across Midden A, from near the topmost part of the midden towards the banks of the River Ythan (Illus 8). Located at the top of the midden mound, SQ1 revealed the densest midden deposits, comprising two thick layers (Illus 9). The upper shell midden layer (108) was around $0.4 \mathrm{~m}$ deep at its thickest point and consisted of a dense deposit composed mainly of mussel shell with quantities of firecracked stone $(c$ 10\%) (Illus 10). The south- east facing section showed that Layer 108 was thicker farther upslope. Examples of nested mussel shells were found in Layer 108, similar to those identified at Midden C. Between this and the lower midden layer were two $c 0.1 \mathrm{~m}$ thick layers of mid-brown sand with a lens of charcoal (110) between them. The lower major shell midden layer (112) was around $0.36 \mathrm{~m}$ deep at its greatest depth and was of identical character to the upper layer. Below this, lenses of mottled brown sand were interspersed with thin lenses of shell and yellow sand, all set within, or lying on top of, a major deposit of windblown sand. Within the windblown sand, lenses of shell and charcoal were identified that are likely to relate to episodes of pit digging of the kind identified in SQ2, where more of the lower windblown sand deposits were revealed.

In SQ2, as in SQ1, two main shell midden layers were identified, but were not as thick, suggesting they may derive from slumping of the deposits from farther up the dune (Illus 11 and 12). However, pit digging was identified below these layers, suggesting that shell processing and/or consumption activity extended into this part of site. Like SQ1, the two shell midden layers (102 and 106) were separated by a layer of sand. Fire-cracked stone was found in both midden layers in similar quantities to that found in the midden layers in SQ1. In the south side of the trench, a series of pits and recuts were evident $(118,119,120$ and 121), each seemingly a re-cut or reuse of the location of previous pit digging events (Illus 12). The pits were all of similar dimensions, less than $c 0.4 \mathrm{~m}$ wide, and each contained thin lenses of degraded shell with occasional charcoal flecks. On the north side of the trench, two pits were evident: 123 and 124 . Pit 123 was of a similar character to the pits described above, if a little larger, and Pit 124 had a greater quantity of shell within its fill. A 19th-century pit (125) containing early modern ceramics cut through the upper shell midden layers. The main shell midden deposits did not extend as far as test pit SQ3, located farther down the slope. Here an old consolidated dune surface was found below windblown sand that was around $1 \mathrm{~m}$ in depth. SQ4 only revealed windblown sand deposits. 


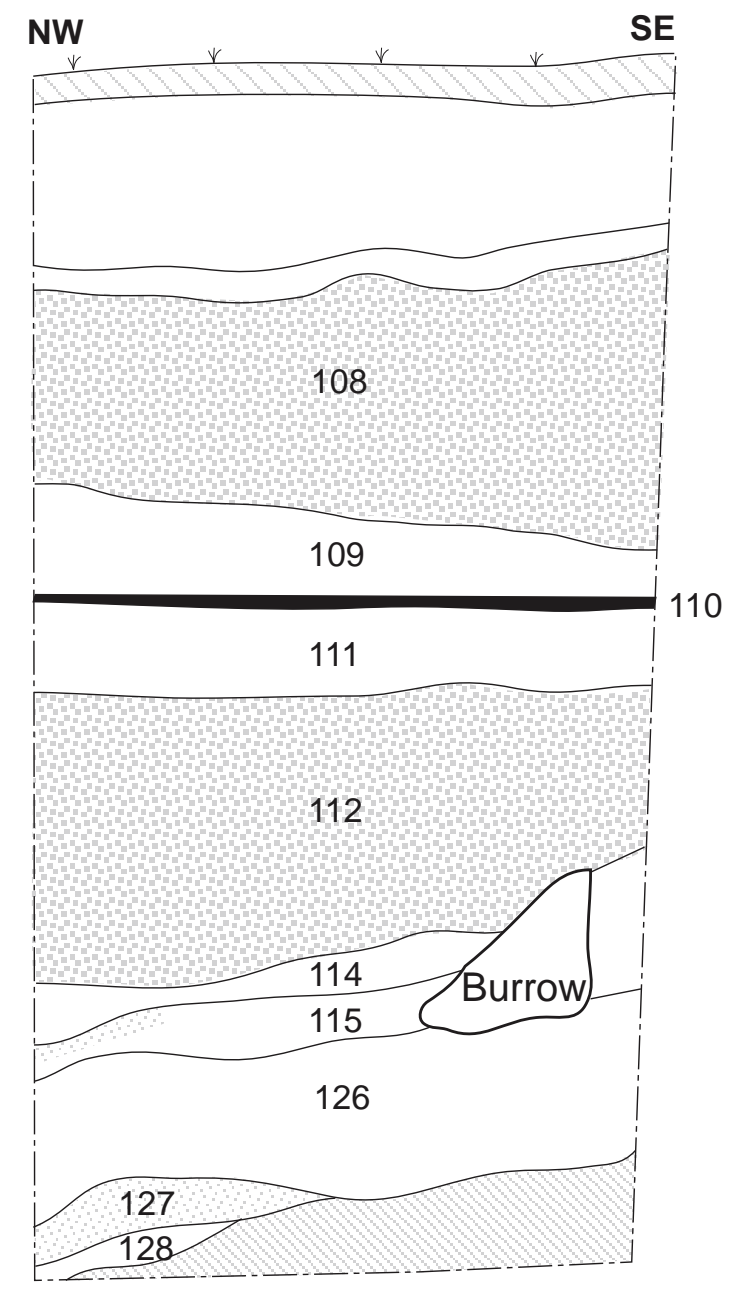

- Charcoal

So Stone

0 Dense Mussel

Mussel

$\square$ Topsoil

$\square$ Wind Blown Sand

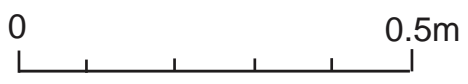

ILLUS 10 South-east facing section of SQ1 Midden A 


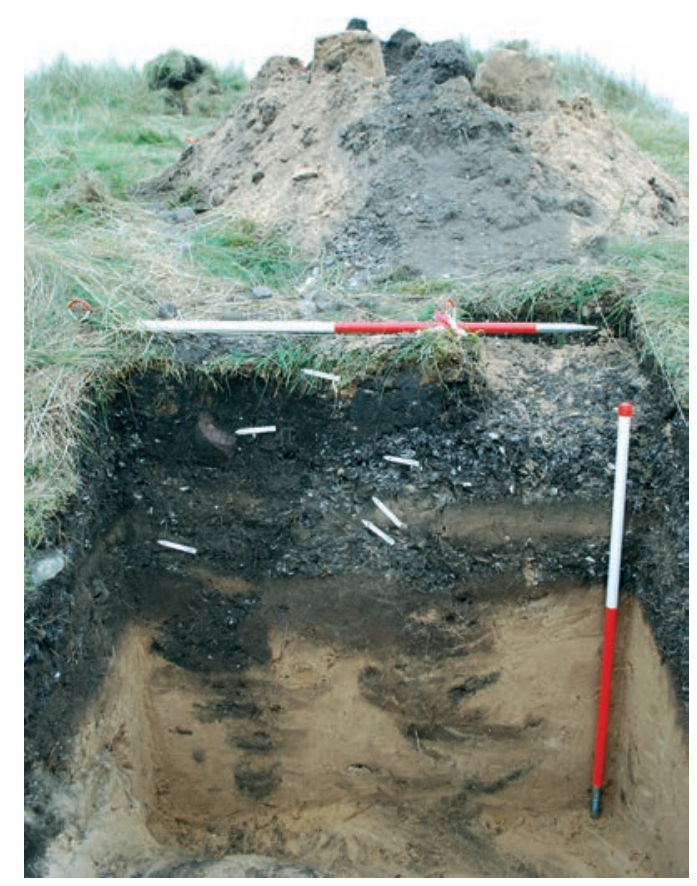

ILLUS 11 South-west facing section of SQ2 Midden A showing two upper shell midden layers with pits cut into sand layers below

\section{MIDDEN B EXCAVATION RESULTS}

Midden B (Illus 13) is an irregularly shaped mound or series of mounds. The length of the midden is around $35 \mathrm{~m}$ north-west/south-east and around $10-15 \mathrm{~m}$ wide north-east/south-west, with the south-westerly portion of the mound eroding down the edge of the MPGT raised beach. The midden is mainly comprised of layers of a similar character to those found at Middens A and C, with mussel dominating much smaller amounts of periwinkle and the occasional cockle shell. Midden B differs in character from Middens $\mathrm{A}$ and $\mathrm{C}$ in that it consists of generally thinner lenses of shell and a small quantity of animal bone. Five test pits were laid out at this site: SQ101 $(1 \times 2 \mathrm{~m})$, SQ102 $(4 \times 1 \mathrm{~m})$, SQ103-105 $(8.5 \times 1 \mathrm{~m})$, SQ112 $(2 \times 1 \mathrm{~m})$ and SQ113 $(1 \times 1 \mathrm{~m})$. In SQ101 the midden was at its thickest, up to
$0.3 \mathrm{~m}$ deep. Separate shell layers were indistinct in most of this test pit, although at least two possible layers were identified. Below the shell layers and dug into the underlying sand lay three fire pits that were recorded, but not excavated. In SQ102 the discrete layers of midden formation were more obvious, with three thin layers of shell (max $0.08 \mathrm{~m}$ thick) (209, 210 and 211) interspersed with mid-brown silty sand lenses (Illus 14). The larger trench, SQ103105 , ran parallel to the main body of the midden (Illus 13). Here, up to $0.2 \mathrm{~m}$ of shell deposits, surviving as two or three layers of shell, were identified lying on top of windblown sand. Multiple fire pits were cut into the lower sand deposits and through the midden layers (Illus 15 and 16). One of the best defined features was a shallow pit (214), up to $0.1 \mathrm{~m}$ in depth, which had a lower fill full of charred roundwood twigs and small branches. A large piece of antler and several antler fragments were also recovered, lying below the midden layers in the south-east corner of the trench (Illus 17). Another unexcavated pit (219) lay at the other end of the trench and demonstrated dense layers of shell and charcoal within the upper fill (Illus 18). Elsewhere in the trench, small pits were identified that had been dug through the upper midden deposits: 216, 217 and 218 (Illus 16). SQ113 contained greater quantities of cockle and periwinkle as well as mussel, and a small number of animal bone fragments were identified, including the proximal end of a cattle ulna (see Table 2).

\section{ANIMAL BONES FROM MIDDEN B}

Midden B was the only midden at the Sands of Forvie to contain animal bones, comprising fragments of red deer antler, a piece of cattle ulna, two ribs fragments of an unidentifiable species, and one unidentifiable bone fragment (Table 2). Overall preservation of the bone was good, especially in the top midden layers, but the antler was less well preserved. The presence of canid gnawing demonstrates the presence of dogs at the site. There was no evidence of burning on the bones, but two fragments show evidence of 
TABLE 2

Animal bones identified in Midden B at the Sands of Forvie

\begin{tabular}{|c|c|l|c|l|}
\hline Find no. & Square & \multicolumn{1}{|c|}{ Element } & Species & \multicolumn{1}{|c|}{ Comments } \\
\hline 303 & 103 & Antler & Red deer & $\begin{array}{l}\text { Cast, large mature stag. No evidence of } \\
\text { working. }\end{array}$ \\
\hline 304 & 103 & Antler & Red deer & $\begin{array}{l}\text { Same antler as find no. 303 (some } \\
\text { fragments can be united). No evidence of } \\
\text { working. }\end{array}$ \\
\hline 333 & 106 & Unidentified & $?$ & $\begin{array}{l}\text { Cattle } \\
\text { (missing olecranon } \\
\text { process) }\end{array}$ \\
\hline 316 & 113 & $\begin{array}{l}\text { Zones C \& D (as specified in Dobney \& } \\
\text { Reilly, 1988). Extensive dog gnawing } \\
\text { of proximal portion. Posterior portion } \\
\text { chopped off. }\end{array}$ \\
\hline 321 & 113 & Rib fragment & $?$ & Cut mark at one end. \\
\hline
\end{tabular}

butchery (the cattle ulna and one unidentified rib fragment), suggesting that there was small-scale consumption of animals at the site. Considering the lack of evidence for nearby contemporary settlement or cultivation (see below), it is likely that the bones are derived from cuts of meat used to provision the shell fish gatherers. It is probable that all of the antler fragments come from the same antler as some of the elements can be refitted. The antler is from a large mature stag and had been naturally shed, suggesting that it had been found and brought to the site, although there is no evidence of working to suggest it was being used for craft production.

\section{RADIOCARBON DATING}

Six radiocarbon dates were obtained from the Midden $\mathrm{C}$ and one date each from Midden $\mathrm{A}$ and Midden B (Tables 3 and 4) (Illus 19). All the samples were single-entities of charcoal from short-lived wood branches and were submitted to the Scottish Universities Environmental Research Centre to be measured by Accelerator Mass Spectrometry (AMS). A Bayesian approach was adopted for the interpretation of the chronology of Midden $\mathrm{C}$ given the range of dates and its deeper stratigraphic sequence (see Buck et al 1996).

Bayesian modelling was conducted using OxCal v4 (Bronk Ramsey 2009) and the internationally agreed calibration curve for the northern hemisphere, IntCal13 (Reimer et al 2013). The model relationships were illustrated using a standard Harris matrix, and the transition between the earlier and later midden activity (early/later Use; Illus 20) was modelled as two discrete boundaries, which allowed for the potential of a hiatus. Furthermore, the date of the massive sandblow event on which hearth setting 33 was placed was estimated in the model (Illus 20; Sand blow).

The model shows good agreement between the radiocarbon dates and the recorded stratigraphic positions of the samples within the midden $\left(\mathrm{A}_{\text {model }}=87\right)$. The low number of dates does not provide a precise model (Steier \& Rom 2000), but provides a basic framework for the chronology of Midden C. The model estimates that the lower midden was forming in cal AD 85-535 (95\% probability; Illus 21; start: Midden C) and probably in cal AD 280-430 (59\% probability). Overall deposition of material in the upper midden began in $\mathrm{cal} A D$ 640-880 (95\% probability; Illus 21 ; bottom: upper 


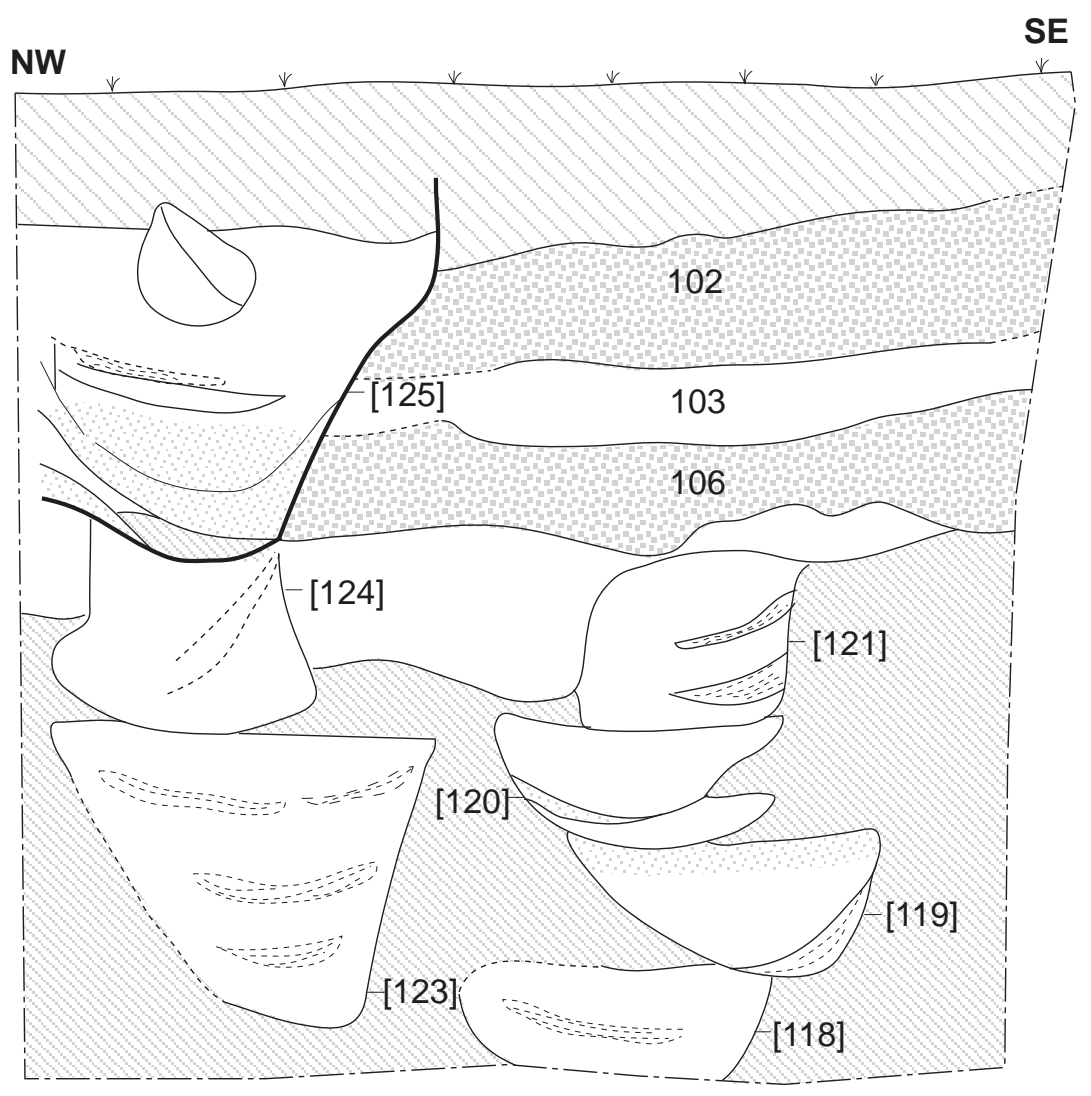

- Charcoal

So Stone

$\square$ Dense Mussel

$\square$ Mussel

$\square$ Topsoil

$\square$ Wind Blown Sand

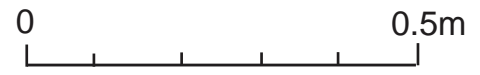

ILLus 12 South-west facing section of SQ2 Midden A 


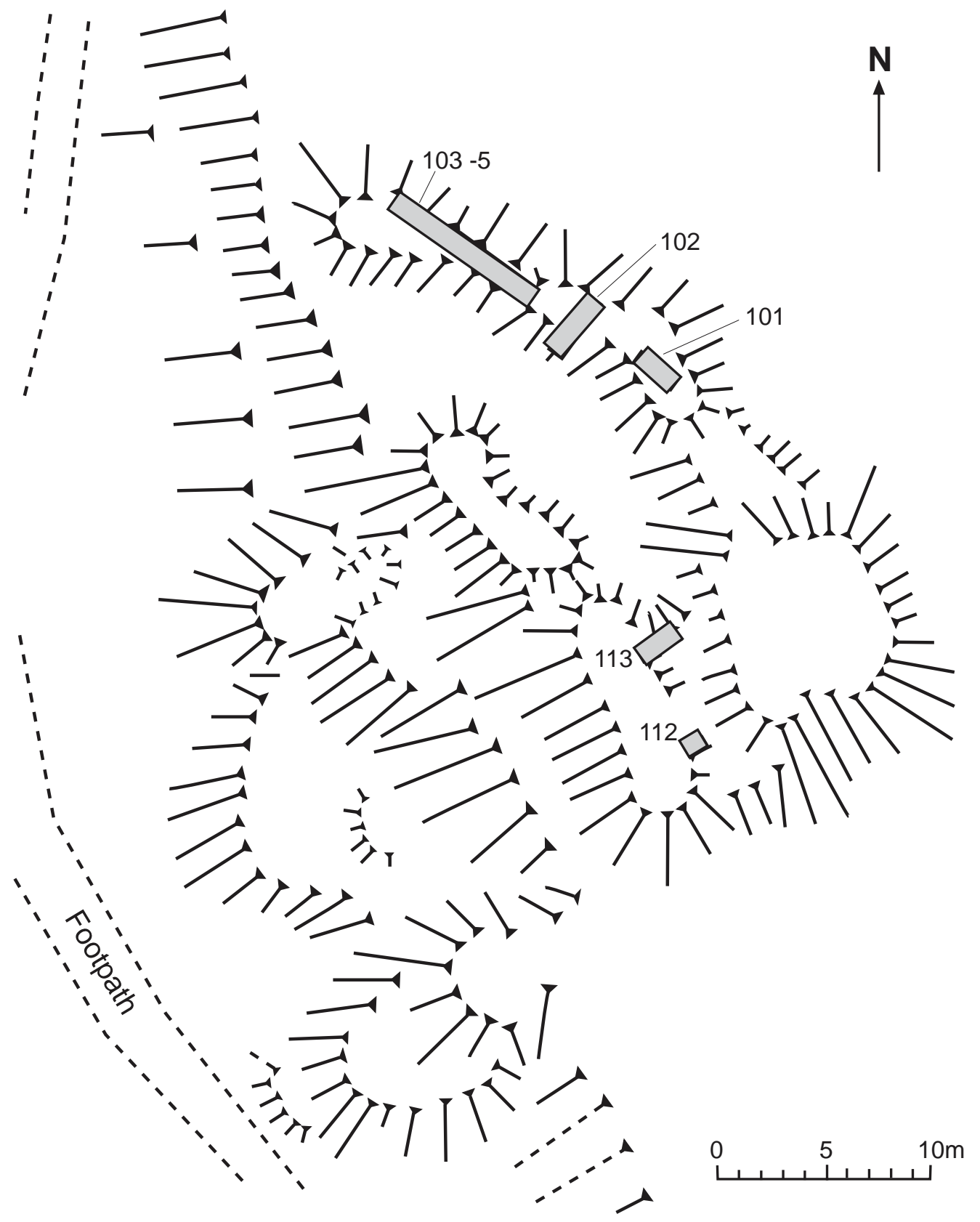

ILLus 13 Hachure survey of Midden B with trench locations marked. Hachure survey based on data from Warren 2005 


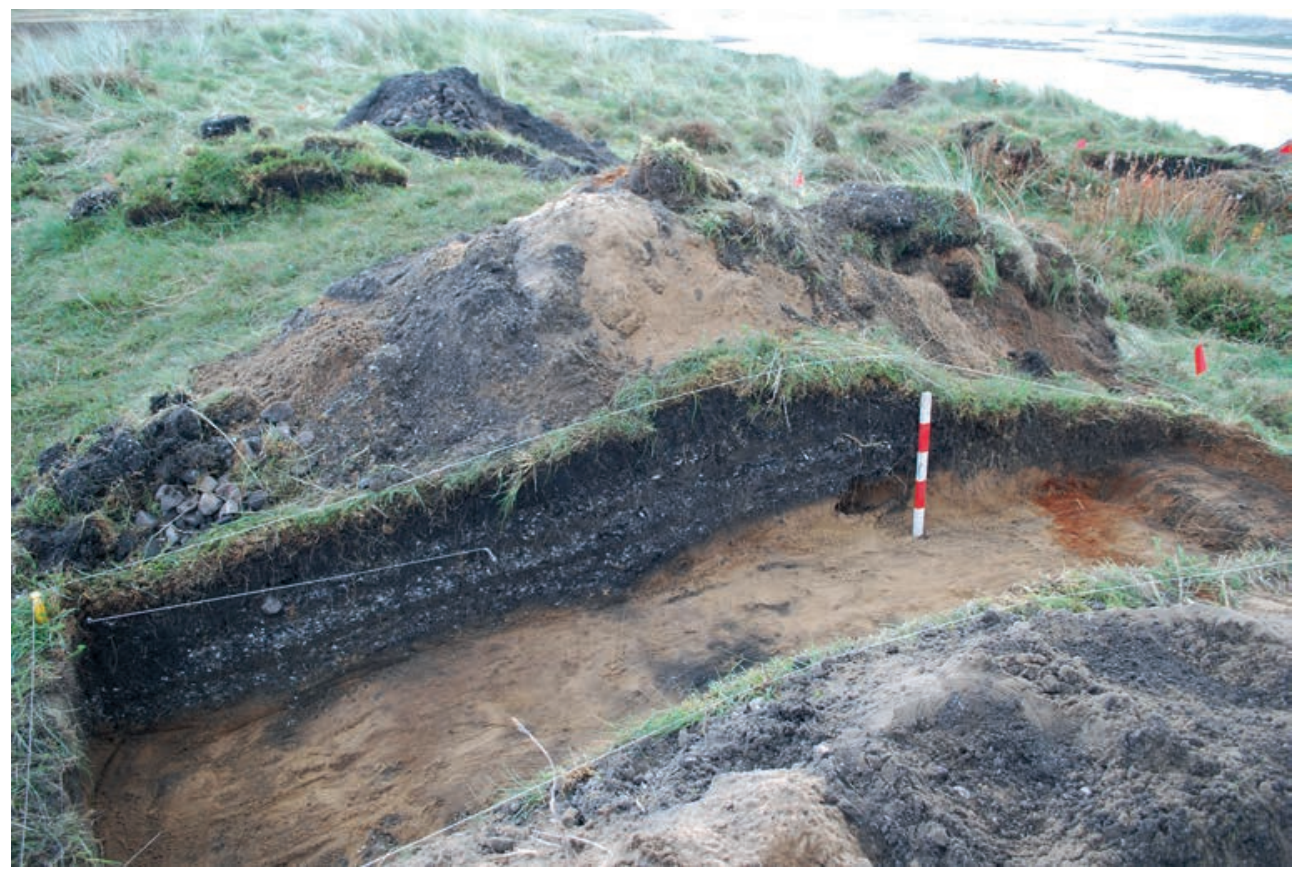

ILLUS 14 Midden B SQ102 with three shell layers evident in the north-east facing section

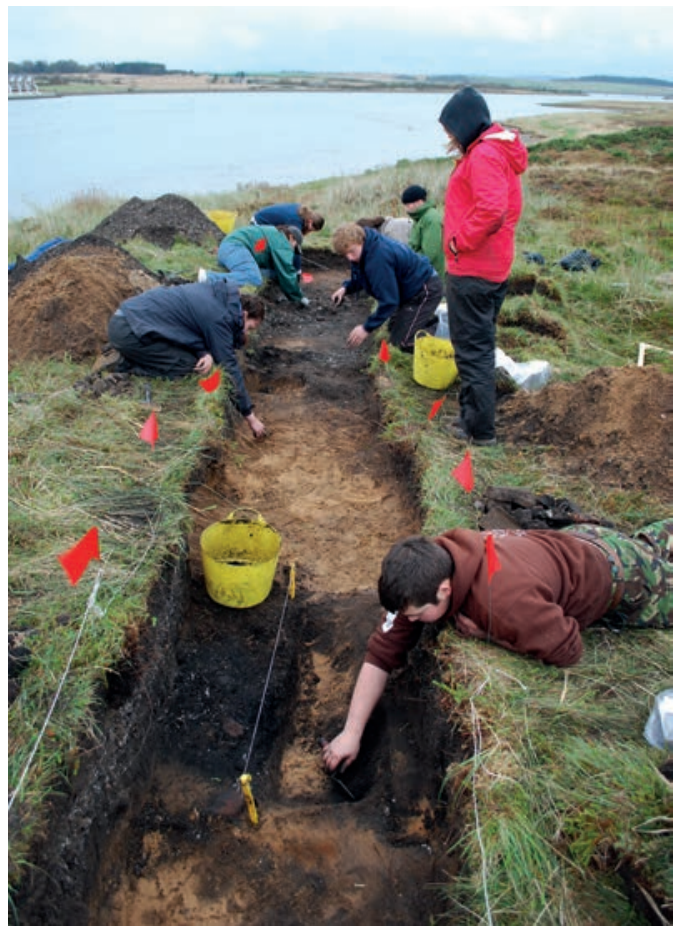

midden) and probably in cal $A D$ 720-840 (68\% probability). The midden ceased being used in cal $A D$ 775-1000 (95\% probability; Illus 21; end: Midden $C)$ and probably in cal $A D$ 805-915 (68\% probability). The deposition of windblown sand took place in cal $A D$ 730-880 (95\% probability; Illus 21; Sand blow) and probably in cal $A D 770$ 850 (68\% probability). Deposition in the upper midden lasted for $1-310$ years $(95 \%$ probability; Illus 22; span: later Use) and probably for 1-135 years $(68 \%$ probability). The radiocarbon date from just below the sand blow is statistically consistent with the three dates from above $\left(\mathrm{T}^{\prime}=3.1 ; \mathrm{v}=3 ; \mathrm{T}^{\prime}(5 \%)=7.8\right)(\mathrm{cf}$ Ward \& Wilson 1978), suggesting the relatively rapid deposition of material from just below the sand blow through to the uppermost portion of the sequence.

ILLUS 15

SQ103-105 showing Fire Pit 214 under excavation.

Photo taken from the south-east 


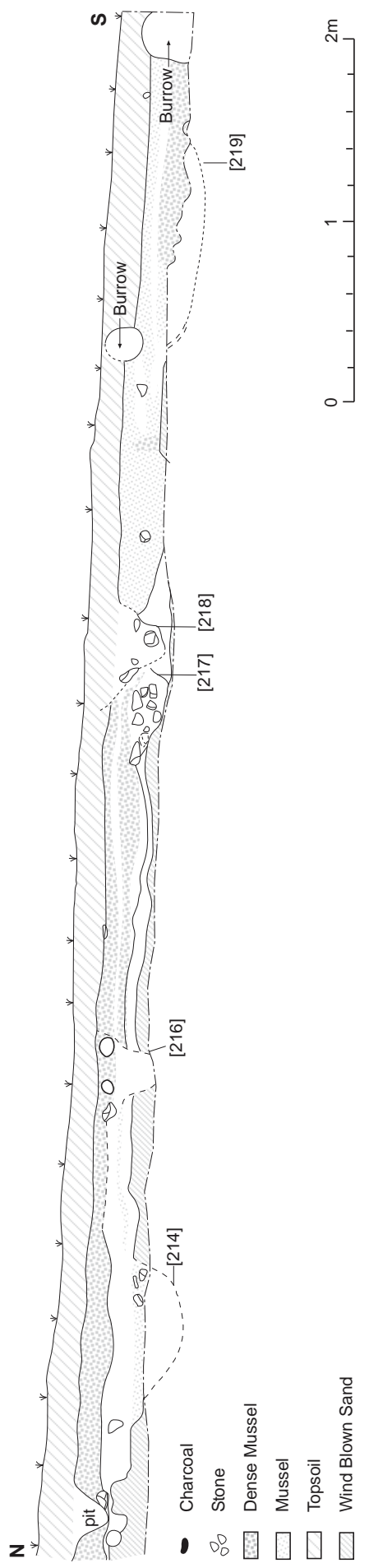

ILLUS 16 SQ103-105 north-east facing section
Only one radiocarbon date is available for Midden B, this shows that the midden was in use in the period cal AD 420-580 (95\% probability) and probably in cal AD 430-550 (68\% probability), broadly contemporary with the lower midden levels at Midden C. Again only one date is available for Midden A and this indicates use in the period cal AD 770-990 (95\% probability) and probably in cal AD 880-970 (68\% probability), broadly contemporary with the latest phases of Midden C.

\section{THE LANDSCAPE OF THE MIDDENS}

Since the excavations in 2010, a series of geophysical, topographical and geoarchaeological landscape surveys have been conducted in the vicinity of the middens. Although the magnetometer survey targeted low-lying areas between the sand dunes, the depth of windblown sand proved to be too great to reveal anomalies associated with anthropogenic features; only drift geology was identified. Around $200 \mathrm{~m}$ north-west of Midden A, test pitting uncovered a homogenous, sandy, ploughed soil buried beneath sand dunes, which contained occasional wood charcoal and charred peat fragments, suggesting that it had been manured with wood and peat ash (Illus 1). Charcoal in this buried agricultural soil was dated to 755-410 and 510-360 cal BC (95\% probability) (Table 5), suggesting that it had been manured in the early Iron Age in an environment that was already receiving considerable inputs of windblown sand. It is not possible to determine on the basis of this small number of dates when this soil began to be cultivated, or how long this cultivation continued. However, if the thick windblown sand layer that separated the upper and lower parts of Midden $\mathrm{C}$ is indicative of a major period of sand movement over this area, it is unlikely that agricultural activity would have been viable after the 8th or 9th centuries $\mathrm{AD}$, when the upper midden deposits of Midden $\mathrm{C}$ and the deposits at Midden A were accumulating. Abandonment of these prehistoric fields may have followed a similar trajectory to the abandonment of Forvie village, which occurred in 1413 as the sandblow 


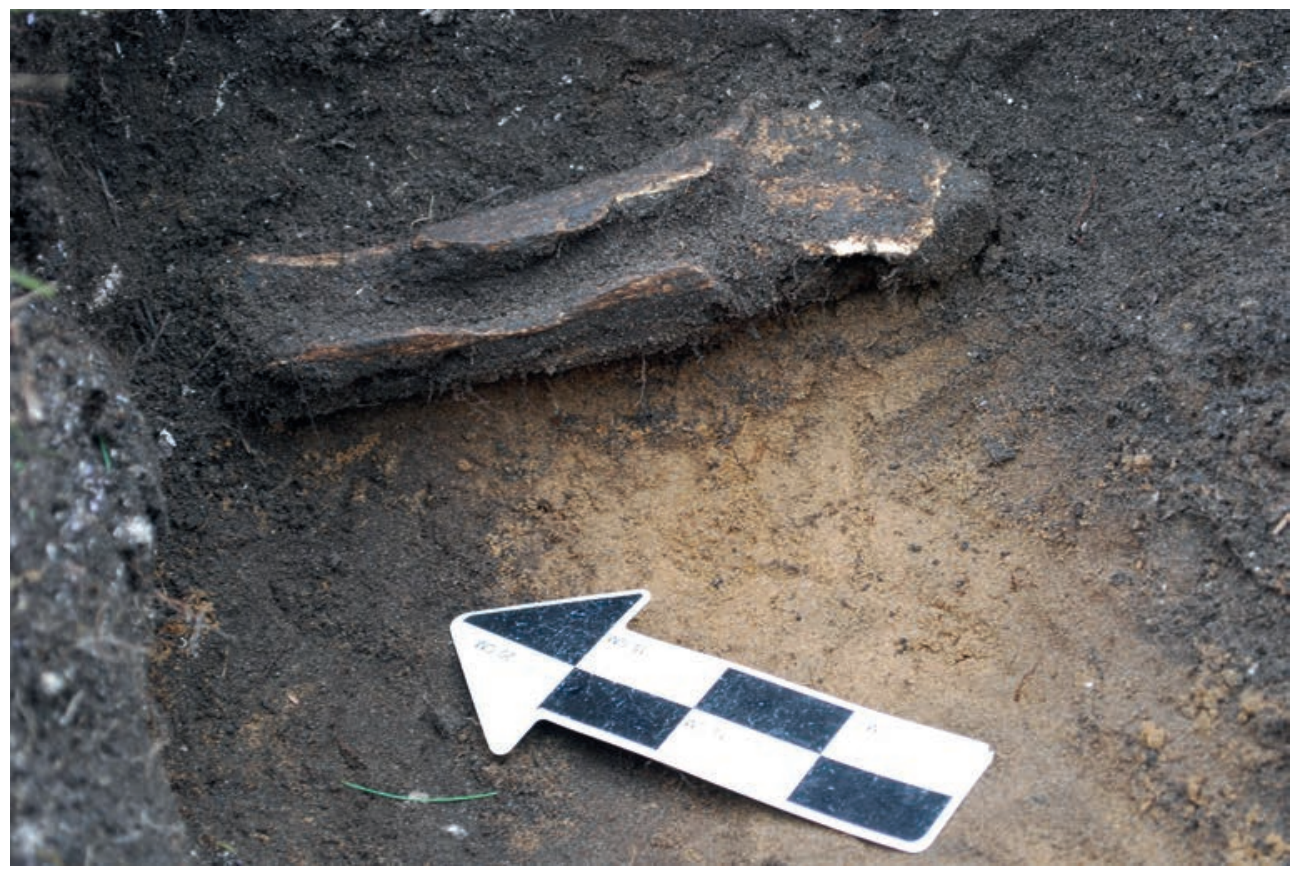

ILLus 17 Antler from SQ103-105

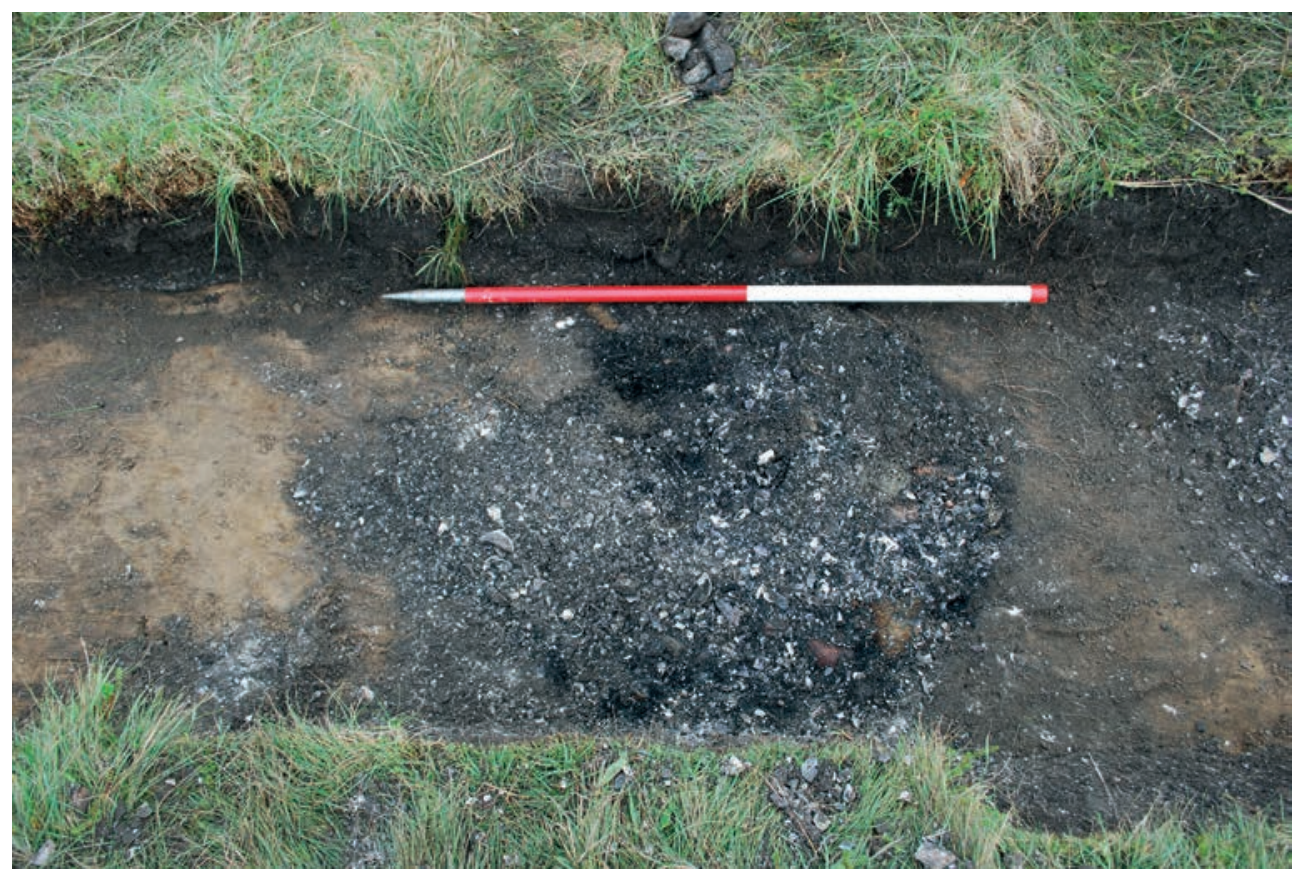

Illus 18 Fire Pit 219 in SQ103-105 Midden B. Photo taken from the south-west 
began to creep northwards from the estuary mouth. By the late 14 th or early 15 th century, sandblow events had reached the location of the medieval village around $2.5 \mathrm{~km}$ north of the middens and after surviving small sand events for many years, the occupants of the medieval village were finally forced to abandon the settlement and their surrounding fields after a major influx of sand (Ralston 1997; Ritchie 1997). Unfortunately, little is known of the economy or fishing traditions of the village to compare to the midden sites.

Closer to the middens, an extensive auger survey conducted in 2014 confirmed that the landscape around the middens was entirely covered by deposits of windblown sand, which in places appeared to cover post-glacial soils, but no buried ploughed soils were found in the vicinity of the middens. While there is no evidence for agricultural use of the area around the middens, the middens themselves indicate the use of the area for shellfish gathering in the later 1st millennium AD, when the landscape probably closely resembled the dune environment that is present today (partially mobile dunes, partially consolidated with dune grass).

In terms of possible contemporary activity around the middens, there are few indicators of other early medieval activity in the Forvie area. Around $100 \mathrm{~m}$ north-east of Midden A a small turf structure was identified during the 2014 survey (Illus 2). This survives on the surface as an oval-shaped earthwork, approximately $10 \mathrm{~m}$ long and $5 \mathrm{~m}$ wide, with a hollow in the middle and raised turf areas around the edges. A test pit revealed that the structure was built on a thick deposit of windblown sand and therefore probably dates to the early medieval period or later. A compact and clearly defined black layer within the structure was identified as a possible floor layer, but no dating material was recovered from the flotation samples, so a more precise date is currently not possible. Given the environment of this area since the incursion of the sand dunes, it is possible that this small, isolated structure represents a medieval or post-medieval structure - such as a shieling used during the summer months, a hunting shelter used during the eider

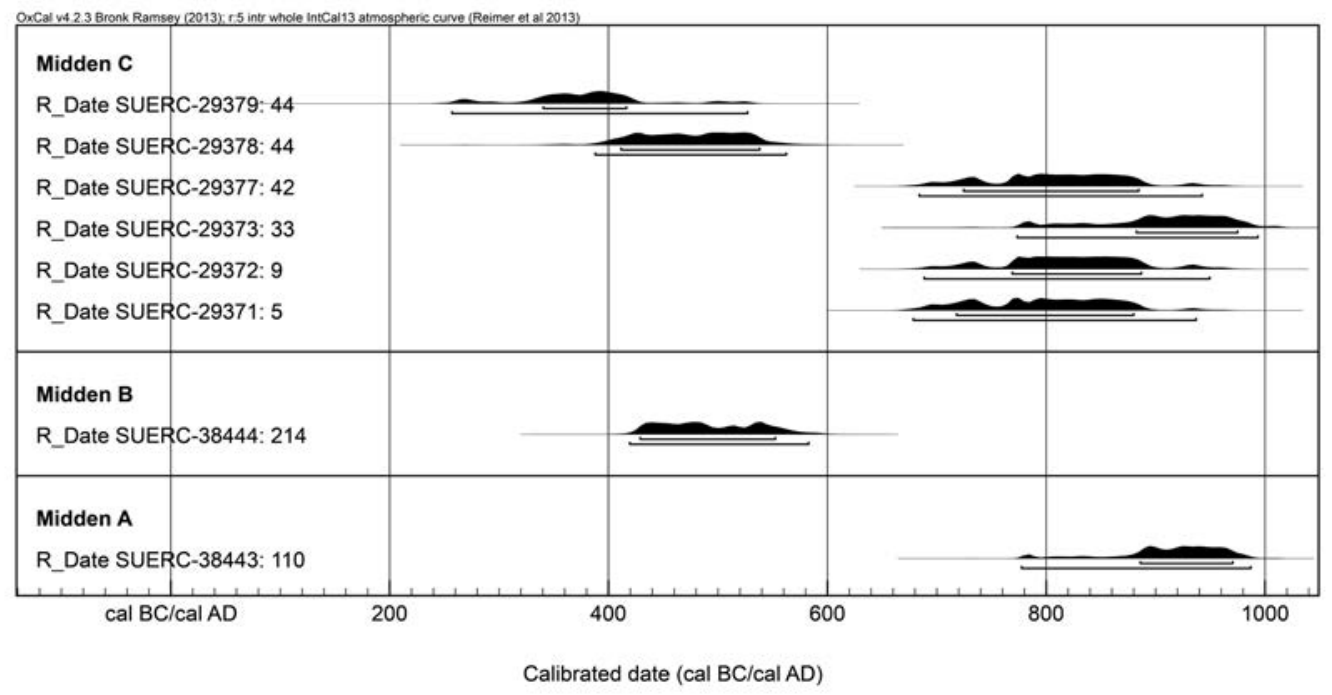

ILlus 19 OxCal plot of radiocarbon dates from Middens A, B and C. Calibrated according to OxCal v4.2.4 


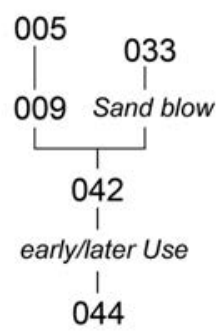

ILLUS 20 Stratigraphic model used for the Bayesian modelling of radiocarbon dates

duck nesting season, or a shelter used during periods of shellfish gathering - but was not a permanent dwelling.

The only other candidate for settlement contemporary to the middens is $3.5 \mathrm{~km}$ to the north at Cluny Cottages, in the north part of the Nature Reserve, where a settlement consisting of turf-built structures has been identified. This site consists of one larger rectilinear building with rounded ends, $17 \mathrm{~m}$ long $\times 8 \mathrm{~m}$ wide, a series of smaller turf structures, and two enclosures, one around $14 \mathrm{~m} \times 14 \mathrm{~m}$ and the other $23 \mathrm{~m} \times 25 \mathrm{~m}$ in maximum extent (Canmore ID 20844). The site has been interpreted as a longhouse with two stock enclosures and a number of outbuildings, although other than the initial recording of surface features no other work has been done at this site. The larger building resembles early medieval Pitcarmick-style houses of the second half of the 1st millennium cal AD (eg Carver et al 2012), but absolute dating will require further fieldwork.

\section{DISCUSSION}

\section{THE SANDS OF FORVIE MIDDENS}

The excavations at the Sands of Forvie uncovered an unexpected depth of archaeological deposits and identified that well-preserved features dug

TABLE 3

Radiocarbon dates from Sands of Forvie Midden C. The date ranges were calculated using the maximum intercept method (Stuiver \& Reimer 1986), and rounded as recommended by Mook (1986)

\begin{tabular}{|c|c|c|c|c|c|c|}
\hline$L a b I D$ & $\begin{array}{c}\text { Context } \\
\text { description } \\
\text { [Context Ref] }\end{array}$ & Material & $\begin{array}{l}\delta^{13} \mathrm{C} \\
(\% o)\end{array}$ & $\begin{array}{c}\text { Radiocarbon } \\
\text { age }(B P)\end{array}$ & $\begin{array}{l}\text { Calibrated } \\
\text { date }(95 \% \\
\text { confidence) }\end{array}$ & $\begin{array}{l}\text { Calibrated } \\
\text { date (68\% } \\
\text { confidence) }\end{array}$ \\
\hline $\begin{array}{c}\text { SUERC- } \\
29371\end{array}$ & $\begin{array}{c}{[(005)} \\
\text { sample 18] }\end{array}$ & $\begin{array}{l}\text { charcoal: } \\
\text { Betula } \mathrm{sp}\end{array}$ & -25.2 & $1220 \pm 40$ & cal AD 680-900 & cal AD 720-880 \\
\hline $\begin{array}{c}\text { SUERC- } \\
29372\end{array}$ & $\begin{array}{c}{[(009)} \\
\text { sample 1] }\end{array}$ & $\begin{array}{l}\text { charcoal: } \\
\text { Betula } \mathrm{sp}\end{array}$ & -27.6 & $1200 \pm 40$ & cal AD 680-950 & cal AD 770-880 \\
\hline $\begin{array}{c}\text { SUERC- } \\
29373\end{array}$ & $\begin{array}{c}{[(033)} \\
\text { sample 78] }\end{array}$ & $\begin{array}{l}\text { charcoal: } \\
\text { Salix sp }\end{array}$ & -27.0 & $1130 \pm 40$ & cal AD 770-990 & cal AD 880-990 \\
\hline $\begin{array}{c}\text { SUERC- } \\
29377\end{array}$ & $\begin{array}{c}{[(042)} \\
\text { sample 87] }\end{array}$ & $\begin{array}{l}\text { charcoal: } \\
\text { Calluna } \\
\text { vulgaris }\end{array}$ & -27.3 & $1210 \pm 40$ & cal AD 680-940 & cal AD 770-880 \\
\hline $\begin{array}{c}\text { SUERC- } \\
29378\end{array}$ & $\begin{array}{c}{[(044)} \\
\text { sample 89] }\end{array}$ & $\begin{array}{l}\text { charcoal: } \\
\text { Betula sp }\end{array}$ & -27.8 & $1590 \pm 40$ & cal AD 390-560 & cal AD 410-540 \\
\hline $\begin{array}{c}\text { SUERC- } \\
29379\end{array}$ & $\begin{array}{c}{[(044)} \\
\text { sample } 89]\end{array}$ & $\begin{array}{c}\text { charcoal: } \\
\text { Corylus } \\
\text { avellana }\end{array}$ & -26.5 & $1665 \pm 40$ & cal AD $250-540$ & cal AD 330-420 \\
\hline
\end{tabular}


TABLE 4

Radiocarbon dates from Sands of Forvie Middens A and B. The date ranges were calculated using the maximum intercept method (Stuiver \& Reimer 1986), and rounded as recommended by Mook (1986)

\begin{tabular}{|c|c|c|c|c|c|c|}
\hline Lab ID & $\begin{array}{c}\text { Context } \\
\text { description } \\
\text { [Context Ref] }\end{array}$ & Material & $\begin{array}{c}\delta^{13} C \\
(\%)\end{array}$ & $\begin{array}{c}\text { Radiocarbon } \\
\text { age (BP) }\end{array}$ & $\begin{array}{c}\text { Calibrated } \\
\text { date (95\% } \\
\text { confidence) }\end{array}$ & $\begin{array}{c}\text { Calibrated } \\
\text { date (68\% } \\
\text { confidence) }\end{array}$ \\
\hline $\begin{array}{c}\text { SUERC- } \\
38443\end{array}$ & $\begin{array}{c}\text { [(110) Sq 1 } \\
\text { sample 205] } \\
\text { Midden A }\end{array}$ & $\begin{array}{c}\text { charcoal: } \\
\text { Salix sp }\end{array}$ & -24.9 & $1130 \pm 30$ & cal AD 770-990 & cal AD 880-970 \\
\hline $\begin{array}{c}\text { SUERC- } \\
38444\end{array}$ & $\begin{array}{c}\text { [(214) Sq 1 } \\
\text { sample 334] } \\
\text { Midden B }\end{array}$ & $\begin{array}{c}\text { charcoal: } \\
\text { Sorbus } \\
\text { aucuparia }\end{array}$ & -25.7 & $1550 \pm 30$ & cal AD 420-580 & cal AD 430-550 \\
\hline
\end{tabular}

into the middens and the underlying windblown sand deposits survive. When the excavations were conducted, the only artefacts found were flint flakes struck from beach cobbles, and prehistoric dates were therefore expected for the shell midden deposits. However, the dates for Middens A and B show that despite speculation in the past (eg Warren 1999; 2005: 65), the accumulation of midden material on the MGPT raised beach is not an indication of the date of features at the Sands of Forvie. The dating from Forvie shows that the three major middens investigated thus far are all 1st millennium AD in date. In all cases, where identifiable, the middens were overwhelmingly dominated by mussels (see Table 1 for detailed analysis of Midden C). Midden B was of a slightly different character to Midden A and Midden C, consisting of thinner

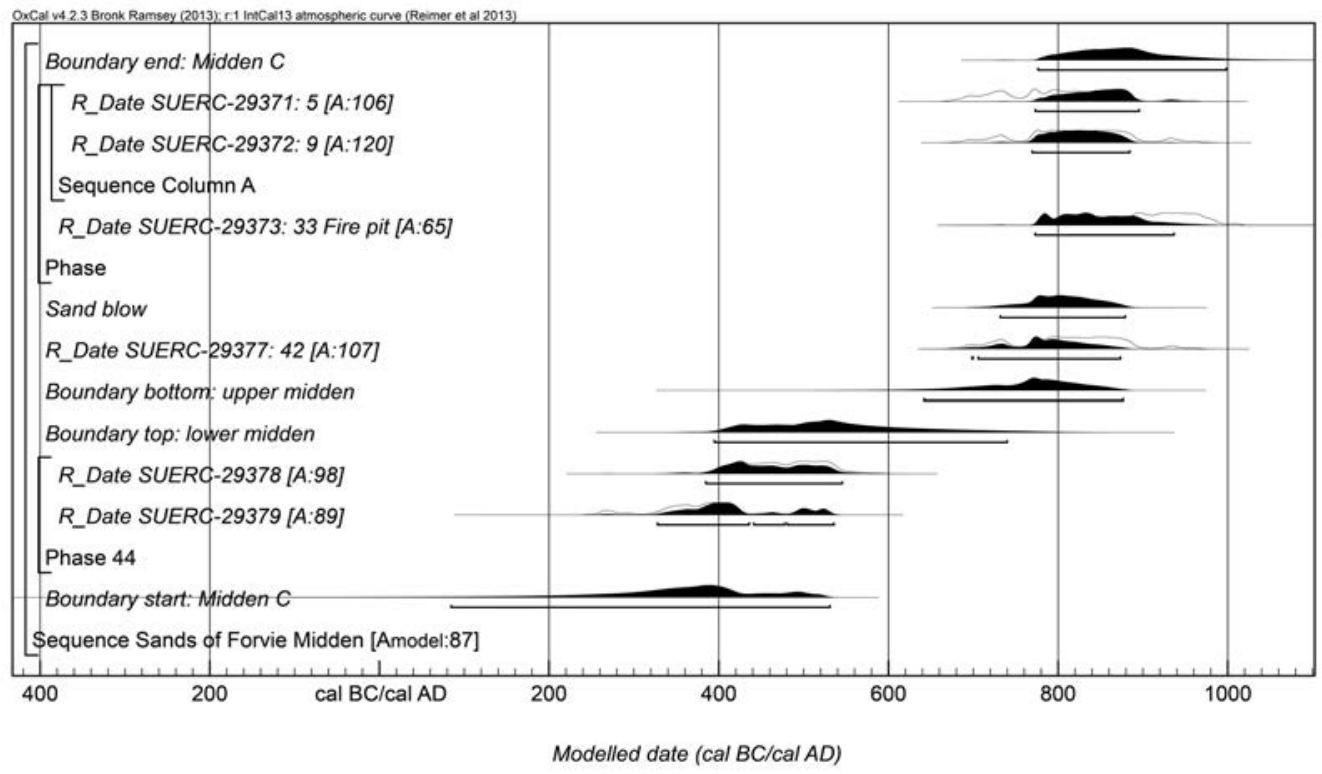

ILLUs 21 Bayesian modelled radiocarbon dates for Sands of Forvie Midden C 


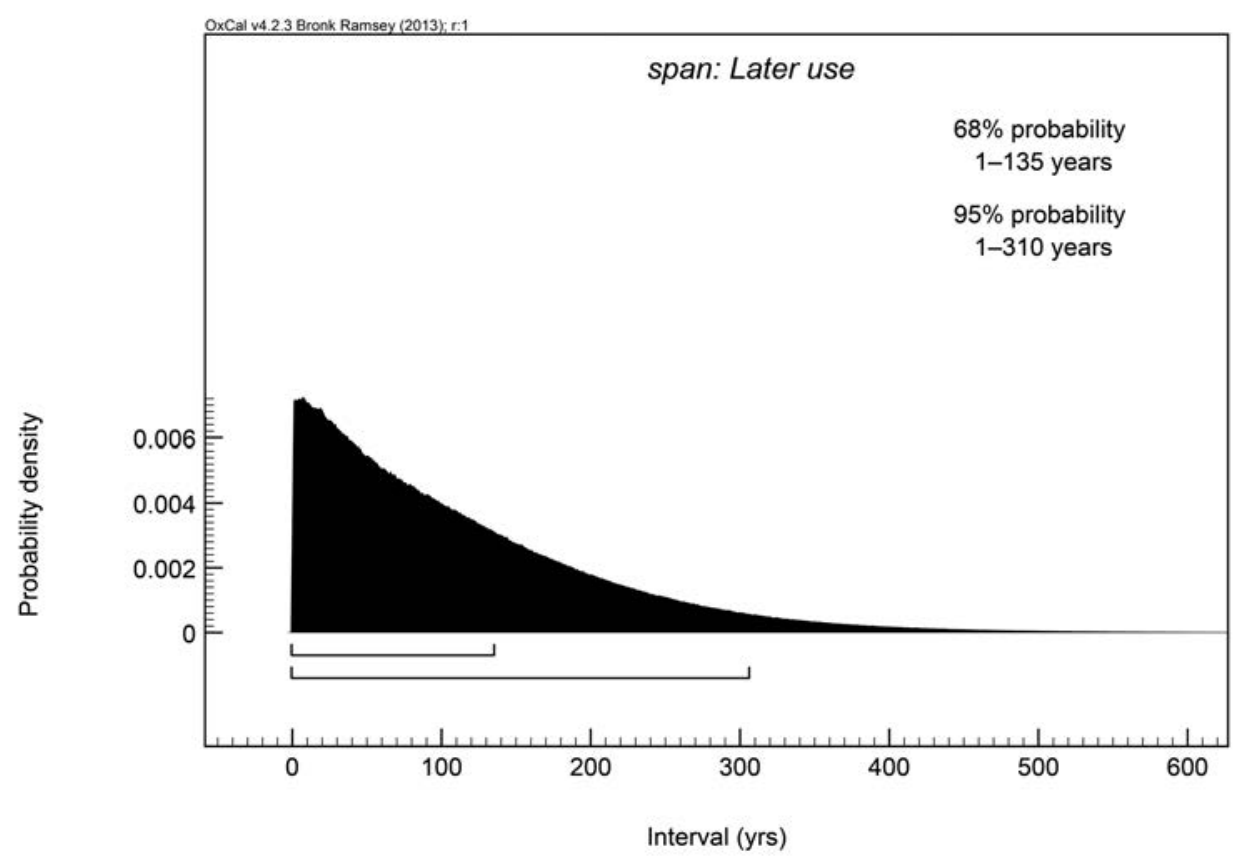

ILlus 22 Span for Midden C

layers of shell and the occasional fragments of animal bone, and the dating suggests this midden was earlier. However, Midden B has also revealed very similar types of activity to that at Middens A and $\mathrm{C}$ - the digging of fire pits for the cooking of mussels and the creation of shell midden layers. At Midden B, the overall midden may have been created over a relatively short period of time (as suggested for the upper part of Midden C) and perhaps by smaller numbers of people than the other two larger and deeper middens.

At all three midden sites, concentrations of fire-cracked stone were found in the midden layers and within pits dug into the midden and into the lower sand deposits. The pits were of a similar character, with fills of charcoal, shell and, in some cases, evidence for recutting. Fire Pit 31, in Midden $\mathrm{C}$, provides an illuminating example. Fire Pit 31 consisted of lower fills of peat and charred wood and branches, and an upper deposit of fire-cracked stone, with a distinct layer of shell above, including whole shells. The composition of these fills provides strong evidence for the cooking of mussels within the fire pit. The recurring presence of pits of this type suggests that the middens were created in the process of cooking mussels for human consumption rather than being the outcome of collecting mussels for other purposes, such as bait for fishing, although a dual use for the shellfish cannot be excluded (Fenton 1992). The absence of fish bones in the midden deposits, which were highly calcareous and provided good preservation conditions for bone, also strongly suggests that this was not a fishing site and that the shellfish were gathered for direct human consumption, either on the spot or taken elsewhere (eg in contrast to the Viking Age midden at Quoygrew, Orkney) (Simpson et al 2005; Harland \& Barrett 2012). None of the other pits identified at Midden $\mathrm{C}$ were as well preserved as Fire Pit 31, but may simply represent pits that were more fully emptied during the collection of the cooked shellfish, with the stone and charcoal perhaps also collected for reuse in other pits. Fire Pit 31 had also probably been cleared out on a previous occasion, but in its last use the charcoal and heated stones were left in situ rather than reused. 
The upper shell midden deposits at Midden $\mathrm{C}$, which were around $1 \mathrm{~m}$ in depth, and the substantial layers in Midden A, both with large quantities of fire-cracked stone, suggest that intensive processing and cooking of mussels took place at the Sands of Forvie in the second half of the 1st millennium AD. From ethnographic accounts, Waselkov (1987) suggests that the main ways of cooking shellfish without prior removal of shell are by baking, whereby the shellfish are placed directly into or nearby a fire; boiling, whereby heated stones are placed into a basket or another container containing water and shellfish; or by steaming, applying water to heated rocks upon which the shellfish are rested. Steaming can take place directly within the fire pit itself or within secondary pits dug specifically for steaming, with the hot stones taken from other fires (eg Parmalee \& Klippel 1974). Baking or steaming seems the most likely methods used for cooking shellfish at the Sands of Forvie, but the different methods are difficult to tell apart archaeologically. Due to the short cooking time, and often the addition of water to shells cooked close to direct heat, burning of the shell is limited even when the shells are placed directly on the fire (Parmalee \& Klippel 1974; Waselkov 1987: 100-5; Thoms 2009).

\section{WIDER PARALLELS}

The quantity of shell midden deposits across Europe is potentially vast, though most areas have not been subject to detailed coastal surveys
(Gutiérrez-Zugasti et al 2011). Milner and Woodman (2007: 101) suggest in excess of around 200 shell middens survive on the coasts of Ireland and the NMRS suggests a similar number exist in Scotland (Illus 23). In Scotland, the best known shell midden sites are the Mesolithic shell middens on Oronsay and in the Inner Sound, and the large Mesolithic-Neolithic shell middens found on the former shores of the Firth of Forth (Sloan 1982; Mellars 1987; Hardy \& WickhamJones 2009). However, a number of middens have been dated to later periods, including the Iron Age, early medieval and Viking Periods and high medieval period (Hardy 2013: 133).

The occurrence of early medieval shell middens has not previously been reviewed in Scotland and their existence is poorly documented. Much of the current evidence relates to Orkney, where a number of early medieval shell bearing sites have been investigated on the west coast of Mainland Orkney, including the Point of Buckquoy, Brough Road and Saevar Howe, all near Birsay (Ritchie 1977; Colley 1983; Brundle et al 2003). At Buckquoy, shellfish were found from the Pictish and Norse phases of occupation. The shellfish consisted primarily of limpet and winkle (Evans \& Spencer 1977). A decrease in limpet size over time was tentatively interpreted as evidence of 'localised over-collection' of shellfish, but there was little indication of whether the shellfish related to direct consumption or use as bait (Ritchie 1977: 191). However, given the relative lack of fishbone in

TABLE 5

Radiocarbon dates from ploughsoil buried under windblown sand. The date ranges were calculated using the maximum intercept method (Stuiver \& Reimer 1986), and rounded as recommended by Mook (1986)

\begin{tabular}{|c|c|c|c|c|c|c|}
\hline$L a b I D$ & $\begin{array}{c}\text { Context } \\
\text { description } \\
\text { [Context Ref] }\end{array}$ & Material & $\begin{array}{l}\delta^{13} C \\
(\% \circ)\end{array}$ & $\begin{array}{c}\text { Radiocarbon } \\
\text { age }(B P)\end{array}$ & $\begin{array}{l}\text { Calibrated } \\
\text { date }(95 \% \\
\text { confidence) }\end{array}$ & $\begin{array}{l}\text { Calibrated } \\
\text { date }(68 \% \\
\text { confidence) }\end{array}$ \\
\hline $\begin{array}{l}\text { SUERC- } \\
40092\end{array}$ & $\begin{array}{l}\text { Buried soil, Test } \\
\text { Pit } 1 \text {, Horizon } 5\end{array}$ & $\begin{array}{l}\text { charcoal: } \\
\text { Salix sp }\end{array}$ & -24.8 & $2450 \pm 30$ & $755-410 \mathrm{cal} \mathrm{вС}$ & $745-415$ cal вс \\
\hline $\begin{array}{l}\text { SUERC- } \\
40093\end{array}$ & $\begin{array}{l}\text { Buried soil, Test } \\
\text { Pit } 1 \text {, Horizon } 5\end{array}$ & $\begin{array}{l}\text { charcoal: } \\
\text { Quercus } \\
\text { sp }\end{array}$ & -27.0 & $2335 \pm 30$ & $510-360 \mathrm{cal} \mathrm{вс}$ & $410-385 \mathrm{cal}$ вС \\
\hline
\end{tabular}


the Pictish levels, it may be that the shellfish were for direct consumption (Wheeler 1977: 214). At Brough Road, Bay of Birsay, shellfish gathering has been identified in 3rd- to 9th-century AD contexts (Rackham 1989). Here limpets were the most commonly gathered types, followed by periwinkle, but the contexts were such that it was difficult to tell if the shellfish was for human consumption or for bait (Rackham 1989: 260). Thick deposits of limpet and whelk shells were also found during 19th- and 20th-century excavations at Saevar Howe, with settlement here dating to both the Pictish and Viking period (Hedges 1983). Again there was little evidence on whether the shellfish were a primary food source or were used as fish bait (Hedges 1983: 113). At a later coastal site at Quoygrew, on Westray, Orkney, midden deposits from the 9th- to 16th-century AD farm mound, as well as an 11thto 13th-century AD coastal fish midden contained abundant shellfish remains, especially limpets, but also periwinkles, cockles, mussels, whelks, clams, scallops, cowries and razor shells (Milner $\&$ Barrett 2012). These were interpreted as fish bait on the basis of analogy to Fenton's (1978: $528,542,585-6$; 1992) ethno-historic research on shellfish as bait (Simpson et al 2005: 368), and on the basis of faunal evidence at this and other sites for a concurrent increase in fishing, and isotopic evidence from contemporary burials for the consumption of marine protein from the top of the food chain (Milner et al 2007), with the possibility left open that the slightly smaller limpets and different mix of taxa from the shell dumps in and around the late medieval house might have been consumed (Milner \& Barrett 2012: 113). However, the evidence from Orkney is far from conclusive, with the role of shellfish in early medieval economies and subsistence difficult to verify.

Most of the middens from Orkney come from settlement sites and are often only partially excavated. Whether these sites can truly be considered to include shell middens or are shellbearing sites is also debatable (the distinction is outlined in Gutiérrez-Zugasti et al 2011: 72). The increased evidence for fishing in the Viking Age may suggest that shellfish from this period were largely used for bait (Barrett et al 1999:
355), but the role of shellfish in the earlier 1stmillennium AD phases of Orkney seems less secure and would repay further investigation and excavation. In the rest of Scotland, few early medieval shell middens have been identified, although in western Scotland, Hardy (2013: 130) has suggested that periwinkle-dominated shell middens may be medieval in date. She identified a series of middens found in association with monastic or religious sites at Ashaig and Skeabost on Skye, Inverie at Knoydart, Finlaggan in Islay and Church Cave on Rona, but few of these sites have been directly dated. Shellfish use has also been documented in the Western Isles in the Iron Age, Viking Age and medieval phases of Bornais, South Uist. This mainly consisted of winkle and limpet shells found in the house floors of structures and the excavator interpreted it as direct consumption of shellfish as an addition to human diets (Sharples 2005: 159; Sharples 2012: 228).

The exploitation of shellfish is not well documented in early medieval Britain more generally, although Bede does refer to various varieties of shellfish in his listing of Britain's natural resources (Biggam 2006: 42). In AngloSaxon England, Mays and Beavan's (2012) investigation of diet in the 5 th to 7 th centuries concluded that in general it was based primarily on terrestrial foods. However, shellfish remains have been found in a variety of contexts, including early Saxon deposits at Bishopstone, Sussex, and Middle Saxon contexts at Lyminge, Kent (Campbell 2010; Mays \& Beavan 2012: 872). At Lyminge, the shellfish remains were dominated by mussels. However, in these contexts the shellfish remains were not found concentrated in large middens, but were more scattered deposits of shells. Larger-scale shell gathering is known in Roman and Saxon contexts along the waterfront in London, and some Roman examples appear to indicate evidence for the farming of these resources; some sites, though rare, appear to represent the collection of millions of oysters (Horsey \& Winder 1992: 61).

The evidence is slightly better documented in Ireland, where a number of coastal shell midden sites associated with early medieval contexts are known, but few radiocarbon dates are available 
(O'Sullivan et al 2014: 116). Some of the Irish sites appear to have been settlements, perhaps seasonal in nature, with relatively small-scale deposits of shell associated (eg Doonloughan, Co Galway) (Murray \& McCormick 2012). These show evidence for associated occupation in the form of surfaces, hearths, finds - including metalwork and beads, and occasionally more substantial structures - and they therefore differ significantly from the Sands of Forvie examples (eg Murray 2007: 128-31). Larger deposits of shell are also known and some of these sites may have played more specialised roles in the early medieval economy of Ireland (eg Mallory \& Woodman 1984). In particular, some of the more extensive midden sites in Ireland may be associated with monastic settlements (O'Sullivan et al 2014: 116-17). The occurrence of broken dogwhelk shells at sites such as Dooey, Co Donegal, also suggests the production of purple dye, and some of these sites also appear to have been involved in metalworking and other craft production activities (Murray 2007: 130-1; Murray \& McCormick 2012).

In northern Europe more generally, the closest parallels for the shell middens at the Sands of Forvie are the Iron AgeViking Age middens of Denmark. Denmark has the highest concentration and most intensively studied shell midden sites in northern Europe, most of which have been found along the coasts of east and south-west Jutland and Zealand. Massive mussel middens appear in the early Iron Age, in the second half of the 1st millennium $\mathrm{BC}$ and generally occur until the later 1st millennium AD. Their size varies greatly, with some examples up to $1 \mathrm{~km}$ in length and $20 \mathrm{~m}$ in width, but most are generally not deeper than $1 \mathrm{~m}$. These middens are dominated by mussels, with some cockle, periwinkle and oyster shells.

The Iron Age and early medieval coastal shell middens in Denmark, which, like the Sands of Forvie examples, are composed mostly of mussels, feature a number of hearth or fire pit features closely comparable to those found at the Sands of Forvie (Andersen 2007: 40-1). These features are characterised by circular concentrations of charcoal, shell and fire-cracked stone. Andersen (2007: 41) also interprets these as cooking pits, or more tentatively suggests they may have been related to the drying or smoking of the mussels. The latter interpretation highlights

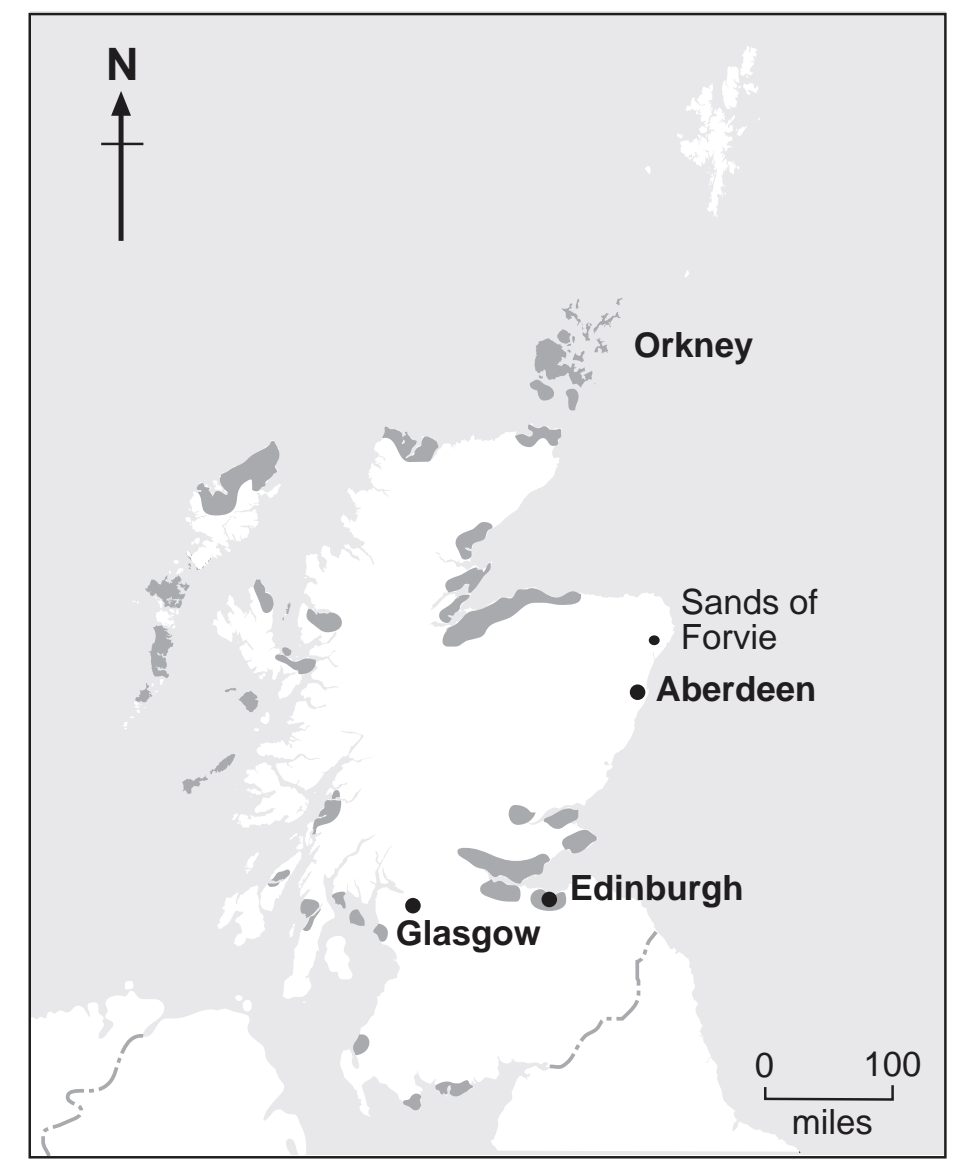

ILLUS 23 Shell middens across Scotland - the main concentrations of shell middens are shaded in grey 
that mussels can be preserved, providing greater economic potential for these coastal resources, and a possible explanation for the fact that they had clearly been gathered intensively on such a large scale.

In Denmark, Andersen interprets the massive mussel middens not as evidence for settlement or due to short-term crises such as famine, but as specialised coastal sites used for concentrated periods of time for the gathering and processing of mussels (Andersen 2007: 41). While smaller than some of the Danish midden sites, the scale of shellfish gathering at Sands of Forvie was still clearly substantial, and like the Danish examples the middens represent a significant investment in labour. The scale and intensity of mussel gathering evident at Middens A and C in particular suggest very intensive phases of midden creation in the late 1st millennium AD. Like the Danish middens (and perhaps similar middens in northern Germany) (Anger 1974), the intensity of use prompts the question of whether consumption was for local use or wider distribution. At the Sands of Forvie, the gathering came at a time when the landscape of the Sands of Forvie was covered by very extensive windblown sands and clearly the area was not used for agriculture at the time of the most intense episodes of midden creation. Given that the area was under constant threat from sand incursions, it could be that a local population had to resort to the use of alternative resources at times of stress. However, there is little evidence for contemporary settlement at the time of midden creation and the character of the middens at the Sands of Forvie is more suggestive of focused, specialised use of a marine resource than expedient use of shellfish at times of stress.

The lack of contemporary soils or evidence for nearby settlement suggests that the Forvie middens were specialised coastal sites that people may have travelled some distance to exploit. As noted previously, in Britain and Ireland there are few comparative sites. However, in Ireland, some midden sites show evidence of economic specialisation with some involved in the production of purple dye or pigment, in some cases associated with metalworking and other craft production activities, and similar evidence is emerging from Anglo-Saxon sites (Biggam 2006; Ceron-Carrasco 2016; Crone \& Hindmarch 2016: 138). The larger-scale middens in Ireland are often found at monastic sites, suggesting that they may have been a feature of early Christian economies associated with monastic landholdings. The Sands of Forvie shellfish gathering occurred on a scale that must have outstripped the needs of individual family groups. For example, the upper midden deposits at Midden C contain up to $140 \mathrm{~m}^{3}$ of shells, and the middens were clearly truncated and therefore larger in the past. Given the quantity of shells, the mussels gathered at the Sands of Forvie may have been exploited to meet the needs of a larger community or perhaps even gathered and processed as an important commodity for trade. If mussels were preserved by cooking, drying or smoking, the mussels would also have had a longer lifespan and even greater economic potential. The processing of mussels on this scale might even indicate their use in tribute or render. For example, the range of products supplied to elites in Anglo-Saxon England could be diverse (Woolf 2007: 24). Shellfish may have also been an important commodity in a Christian context as an important dietary requirement during fast days and would have had limited effect on isotopic signatures (Barrett et al 2004; Milner et al 2004). Isotopic studies of pre-Viking Age early medieval populations in Scotland suggest limited marine contributions to diet, but in Orkney at least, there is evidence for increasing fish consumption in the Viking Age, in the later centuries of the 1 st millennium $\mathrm{AD}$ (eg Barrett \& Richards 2004; Curtis-Summers et al 2014). This later 1st-millennium AD context is the period to which the largest shell deposits at Forvie belong, and it may be that the middens are associated with changes in diet, economy and perhaps settlement form that accompanied the broader changes of the late 1st millennium AD. Whatever the precise interpretation of the middens, it is clear that coastal resources played a hitherto unknown but important role in the early medieval economy of north-east Scotland. The Sands of Forvie middens can perhaps begin to provide insight into the emergence of more specialised economies in the later 1 st millennium 
AD that focused on locally abundant resources, of a character rarely documented.

\section{CONCLUSIONS}

The excavations at the Sands of Forvie have provided surprising new evidence for intensive shellfish gathering and consumption in the 1st millennium AD. In Britain and Ireland, the use of shellfish on many sites is poorly understood, but the Sands of Forvie evidence provides direct evidence for consumption or trade in shellfish on a relatively large scale. Elsewhere in Britain and Ireland there are a limited number of examples of the specialised use of shellfish on anything other than a subsistence base. The most direct parallel for the middens at the Sands of Forvie are perhaps the mussel middens of Denmark, which have been suggested to be intensive and specialised sites for the seasonal production of cooked shellfish on a near 'industrial' scale. There is great potential for new programmes of work at sites such as Sands of Forvie to uncover hitherto unknown elements of the economy and subsistence patterns of early medieval communities in Scotland. The middens at Forvie date prior to the 'fish event horizon' of around $\mathrm{AD}$ 1000, when fish consumption increased and fishing became an important part of the economy of north-west Europe (Barrett \& Richards 2004: 249; Barrett et al 2011). Overall, the new evidence from the Sands of Forvie can perhaps open up a new chapter in the study of the historic use of coastal resources that can prompt a re-evaluation of the role of these resources in the developing economies, trade patterns and diets of 1st-millennium AD societies in Scotland.

\section{REFERENCES}

Andersen, S H 2007 'Shell middens ("Køkkenmøddinger") in Danish prehistory as a reflection of the marine environment', in Milner, N, Craig, O E \& Bailey, G N (eds) Shell Middens in Atlantic Europe, 31-45. Oxford: Oxbow Books.

Anger, K 1974 'Untersuchungen an eisenzeitlichen Muschelhaufen an der Flensburger Förde', Offa 30: 55-9.
Ballantyne, C K \& Dawson, A G 2003 'Geomorphology and Landscape Change', in Edwards, K J \& Ralston, I B M (eds) Scotland After the Ice Age: Environment, Archaeology and History $8000 \quad B C-A D$ 1000, 109-25. Edinburgh: Edinburgh University Press.

Barrett, J H, Nicholson, R H \& Cerón-Carrasco, R 1999 'Archaeo-ichthyological evidence for long-term socioeconomic trends in northern Scotland: 3500 BC to AD 1500', Journal of Archaeological Science 26: 353-88. https:// doi.org/10.1006/jasc.1998.0336.

Barrett, J H, Orton, D, Johnstone, C, Harland, J, Van Neer, W, Ervynck, A, Roberts, C, Locker, A, Amundsen, C \& Enghoff, I B 2011 'Interpreting the expansion of sea fishing in medieval Europe using stable isotope analysis of archaeological cod bones', Journal of Archaeological Science 38(7): 1516-24.

Barrett, J H \& Richards, M P 2004 'Identity, gender, religion and economy: new isotope and radiocarbon evidence for marine resource intensification in early historic Orkney, Scotland, UK', European Journal of Archaeology 7(3): 249-71.

Biggam, C P 2006 'Knowledge of whelk dyes and pigments in Anglo-Saxon England', AngloSaxon England 35: 23-55.

Bronk Ramsey, C 2009 'Bayesian analysis of radiocarbon dates', Radiocarbon 51(1): 337-60.

Brundle, A, Lorimer, D H \& Ritchie, A 2003 'Buckquoy revisited', in Downes, J \& Ritchie, A (eds) Sea Change: Orkney and Northern Europe in the Later Iron Age AD 300 800, 95-104. Angus: Pinkfoot Press.

Buck, C E, Cavanagh, W G \& Litton, C D 1996 Bayesian Approach to Interpreting Archaeological Data. Chichester: John Wiley \& Sons Ltd.

Campbell, G 2010 Assessment of the Archaeological Potential of the Sieved Middle Saxon Molluscs Sieved From Lyminge, Kent. Unpublished report, University of Reading. https://www.reading.ac.uk/web/FILES/ archaeology/Campbel1_2011._Mollusc_ assessment_report.pdf. Accessed 15 February 2017.

Carver, M O H, Barrett, J, Downes, J \& Hooper, J 2012 'Pictish-period byre-houses at Pitcarmick 
and their landscape: investigations 1993-5', Proc Soc Antiq Scot 142: 145-99.

Ceron-Carrasco, R 2016 'Marine molluscs', in Crone \& Hindmarch: 123-4.

Colley, S M 1983 'Marine resource exploitation', in Hedges: 111-13.

Cowie, T G 1996 'Torrs Warren, Luce Sands, Galloway', Transactions of the Dumfriesshire and Galloway Natural History and Antiquarian Society 45: 44-71.

Crone, A \& Hindmarch, E 2016 Living and Dying at Auldhame, East Lothian; The Excavation of an Anglian Monastic Settlement and Medieval Parish Church. Edinburgh: Society of Antiquaries of Scotland.

Curtis-Summers, S, Montgomery, J \& Carver, M 2014 'Stable isotope evidence for dietary contrast between Pictish and medieval populations at Portmahomack, Scotland', Medieval Archaeology 58(1): 21-43.

Dalrymple, C E 1868 'Notes on the excavation of two shell-mounds on the eastern coast of Aberdeenshire', Proc Soc Antiq Scot 6: 423-6.

Dobney, K \& Reilly, K 1988 'A method for recording archaeological animal bones: the use of diagnostic zones', Circaea 5: 79-96.

Evans, J G \& Spencer, P 1977 'The mollusca and environment, Buckquoy, Orkney', in Ritchie, A: 215-19.

Farquhar, A 1799 'The Parish of Slains', The Statistical Account of Scotland 1791-99, 27586.

Fenton, A 1978 The Northern Isles: Orkney and Shetland. East Linton: Tuckwell Press.

Fenton, A 1992 'Shellfish as bait: the interface between domestic and commercial fishing', in Smout, T C (ed.) Scotland and the Sea, 13753. Edinburgh: John Donald.

Griffiths, D \& Ashmore, P 2011 'Introduction: Aeolian Archaeology: The Archaeology of Sand Landscapes in Scotland', in Griffiths, D \& Ashmore, P (eds) 'Aeolian Archaeology: the Archaeology of Sand Landscapes in Scotland', Scottish Archaeological Internet Reports 48: $1-8$.

Gutiérrez-Zugasti, I, Andersen, S H, Araújo, A C, Dupont, C, Milner, N \& Monge-Soares, A M 2011 'Shell midden research in Atlantic Europe: State of the art, research problems and perspectives for the future', Quaternary International 239: 70-85.

Hansom, J D 2003 'Forvie', in May, V J \& Hansom, J D (eds) Coastal Geomorphology of Great Britain. Peterborough: Geological Conservation Review Series No. 28, Joint Nature Conservation Committee. http://jncc. defra.gov.uk/pdf/gcrdb/GCRsiteaccount 1067 . pdf. Accessed 15 February 2017.

Hardy, K 2013 'The Shell Middens of Scotland's Inner Hebrides', in Bailey, G N, Hardy, K \& Camara, A (eds) Shell Energy: Mollusc Shells as Coastal Resources, 123-36. Oxford: Oxbow Books.

Hardy, K \& Wickham-Jones, C (eds) 2009 'Mesolithic and Later Sites around the Inner Sound, Scotland: The work of the Scotland's First Settlers Project 1998-2004', Scottish Archaeological Internet Reports 31.

Harland, J F \& Barrett, J H 2012 'The Maritime Economy: Fish Bone', in Barrett, J (ed.) Being an Islander: Production and Identity at Quoygrew, Orkney, AD 900-1600, 115-38. Cambridge: McDonald Institute Monographs.

Hawke-Smith, C F 1980 'Two Mesolithic Sites near Newburgh, Aberdeenshire', Proc Soc Antiq Scot 110: 497-520.

Hedges, J W 1983 'Trial excavations on Pictish and Viking settlements at Saevar Howe, Birsay, Orkney', Glasgow Archaeological Journal 10: 73-124.

Horsey, I P \& Winder, J M 1992 'The Late Saxon and Conquest Period Oyster Middens', in Jarvis, K S (ed.) Excavations in Poole 19731983, 60-6. Dorchester: Dorset Natural History and Archaeological Society Monograph Series Number 10.

Jamieson, T 1865 'On some remains of the Stone Period in the Buchan district of Aberdeenshire', Proc Soc Antiq Scot 6: 240-45.

Kirk, W 1954 'Sands of Forvie', Discovery and Excavation in Scotland 1954: 5-6.

Kirk, W 1955 'Sands of Forvie', Discovery and Excavation in Scotland 1955: 3-4.

Mallory, J P \& Woodman, P C 1984 'Oughtymore: an early Christian shell midden', Ulster Journal of Archaeology 47: 51-62. 
Mays, S \& Beavan, N 2012 ‘An investigation of diet in early Anglo-Saxon England using carbon and nitrogen stable isotope analysis of human bone collagen', Journal of Archaeological Science 39: 867-74.

Mellars, P A 1987 Excavations on Oronsay. Prehistoric Human Ecology on a Small Island. Edinburgh: Edinburgh University Press.

Milner, N \& Barrett, J 2012 'The Maritime Economy: Mollusc Shell', in Barrett, J (ed.) Being an Islander: Production and Identity at Quoygrew, Orkney, AD 900-1600, 103-13. Cambridge: McDonald Institute Monographs.

Milner, N, Barrett, J \& Welsh, J 2007 'Marine resource intensification in Viking Age Europe: the molluscan evidence from Quoygrew, Orkney', Journal of Archaeological Science 34: 1461-72.

Milner, N \& Woodman, P 2007 'Deconstructing the myth of Irish shell middens', in Milner, N, Craig, O E \& Bailey, G N (eds) Shell Middens in Atlantic Europe, 101-10. Oxford: Oxbow Books.

Milner, N, Craig, O E, Bailey, G N, Pedersen, K \& Andersen, S H 2004 'Something fishy in the Neolithic? A re-evaluation of stable isotope analysis of Mesolithic and Neolithic coastal populations', Antiquity 78(299): 9-22.

Mook, W G 1986 'Business meeting: Recommendations/Resolutions adopted by the Twelfth International Radiocarbon Conference', Radiocarbon 28: 799.

Murray, E 2007 'Molluscs and Middens: The Archaeology of "Ireland's Early Savage Race"?', in Murphy, E M \& Whitehouse, N J (eds) Environmental Archaeology in Ireland, 119-35. Oxford: Oxbow Books.

Murray, E \& McCormick, F 2012 'Doonloughan: a seasonal settlement site on the Connemara coast', Proceedings of the Royal Irish Academy 112(C): 95-146.

North, S 1981 The sands of Forvie and Ythan Estuary National Nature Reserve: a description. Nature Conservancy Council (North-East Scotland Region).

O'Dell, A C 1960 'Ardlethen Farm, Ellon', Discovery and Excavation in Scotland 1960: 2.
O'Sullivan, A, McCormick, F, Kerr, T R \& Harney, L 2014 Early Medieval Ireland $A D$ 400-1100: The Evidence from Archaeological Excavations. Dublin: Royal Irish Academy Monographs.

Parmalee, P W \& Klippel, W E 1974 'Freshwater Mussels as a Prehistoric Food Resource', American Antiquity 39(3): 421-34.

Rackham, D J 1989 'Marine Shellfish' in Morris, C D (ed.) The Birsay Bay Project Volume 1. Coastal Sites beside the Bough Road, Birsay, Orkney. Excavations 1876-1982, 259-62. Durham: University of Durham Department of Archaeology Monograph Series Number 1.

Ralston, I 1997 'The archaeology of the Sands of Forvie and the Ythan valley', in Gorman, M L (ed.) The Ythan: Festschrift for Professor George M. Dunnet, 20-37. Aberdeen: Department of Zoology, University of Aberdeen.

Ralston, I \& Sabine, K A 2001 Excavations of Second and First Millennia $B C$ remains on the Sands of Forvie, Slains, Aberdeenshire. Aberdeen: Department of Geography and Environment, University of Aberdeen, O'Dell Memorial Monograph 28.

Reimer, P, Bard, E, Bayliss, A, Beck, J, Blackwell, P, Bronk Ramsey, C, Buck, C, Cheng, H, Edwards, R, Friedrich, M, Grootes, P, Guilderson, T, Haflidason, H, Hajdas, I, Hatté, C, Heaton, T, Hoffmann, D, Hogg, A, Hughen, K, Kaiser, K, Kromer, B, Manning, S, Niu, M, Reimer, R, Richards, D, Scott, E, Southon, J, Staff, R, Turney, C, \& Van Der Plicht, P 2013 'IntCal13 and Marine13 Radiocarbon Age Calibration Curves 0-50,000 Years cal BP', Radiocarbon 55: 1869-87.

Ritchie, A 1977 'Excavation of Pictish and Vikingage farmsteads at Buckquoy, Orkney', Proc Soc Antiq Scot 108: 174-227.

Ritchie, W 1983, 'Sands of Forvie', in Ritchie, W (ed.) Northeast Scotland coastal field guide and geographical essays, 12-19. Aberdeen: Department of Geography, University of Aberdeen.

Ritchie, W 1997 'The Geomorphology of the Sands of Forvie', in Gorman, M L (ed.) The Ythan, A Festschrift for George Dunnet, 6-18. 
Aberdeen: Department of Zoology, University of Aberdeen.

Rust, J 1845 'Parish of Slains', New Statistical Account of Scotland 1834-45, 589-98.

Saville, A 2004 'Macharmuir (Logie Buchan parish), Mesolithic flints', Discovery and Excavation in Scotland 5: 17.

Scottish Natural Heritage 2009 Scottish National Nature Reserves. Forvie - Setting the Scene. http://www.nnr-scotland.org.uk/forvie/natureand-culture/setting-the-scene/. Accessed 15 February 2017.

Sharples, N 2005 'Comparative analysis of floors and middens: Marine shell', in Sharples, N (ed.) A Norse Farmstead in the Outer Hebrides: Excavations at Mound 3, Bornais, South Uist, 146-7. Oxford: Oxbow Books.

Sharples, N 2012 'Resource exploitation: The Shore 1. Shellfish', in Sharples, N (ed.) A Late Iron Age Farmstead in the Outer Hebrides: Excavations at Mound 1, Bornais, South Uist, 228. Oxford: Oxbow Books.

Shepherd, I 1983 'Foveran Links, flint working site', Discovery and Excavation in Scotland 1983: 11.

Simpson, I A, Barrett, J H \& Milek, K B 2005 'Interpreting the Viking Age to Medieval Period transition in Norse Orkney through cultural soil and sediment analysis', Geoarchaeology 20(4): 355-77.

Sloan, D 1982 'Nether Kinneil', Current Archaeology 84: 13-15.

Sneddon, J \& Ralston, I 1984 'Mains of Waterton (Ellon parish), Flint artefacts', Discovery and Excavation in Scotland 1984: 11.
Sneddon, J \& Shepherd, I 1985 'Mains of Waterton (Ellon parish), Mesolithic rockshelter, possible', Discovery and Excavation in Scotland 1985: 17.

Steier, P \& Rom, W 2000 'The use of Bayesian statistics for ${ }^{14} \mathrm{C}$ dates of chronologically ordered samples: a critical analysis', Radiocarbon 42: 183-98.

Stuiver, M \& Reimer, P J 1986 'A computer program for radiocarbon age calibration', Radiocarbon 28: 1022-30.

Thoms, A V 2009 'Rocks of ages: propagation of hot-rock cookery in western North America', Journal of Archaeological Science 36: 573-91.

Ward, G K \& Wilson, S R 1978 'Procedures for comparing and combining radiocarbon age determinations: a critique', Archaeometry 20: 19-32.

Warren, G 1999 'Sands of Forvie (Slains parish), Mesolithic lithic scatters and middens', Discovery and Excavation in Scotland 1999: $10-11$.

Warren, G 2005 Recent fieldwork at the Sands of Forvie, Aberdeenshire. Unpublished report, University of Dublin.

Waselkov, G A 1987 'Shellfish Gathering and Shell Midden Archaeology', Advances in Archaeological Method and Theory 10: 92210.

Wheeler, A 1977 'The fish bones from Buckquoy, Orkney', in Ritchie, A: 211-14.

Woolf, A 2007 From Pictland to Alba, 789-1070. Edinburgh: Edinburgh University Press. 